\title{
Cave development in an uplifting fold-and-thrust belt: case study of the Tatra Mountains, Poland
}

\author{
Jacek Szczygieł \\ Department of Fundamental Geology, Faculty of Earth Sciences, University of Silesia, Będzińska 60, 41-200 Sosnowiec, Poland
}

\begin{abstract}
Detailed structural analysis and geomorphological observations supplemented by the analysis of the distribution of karst conduit directions have been performed in 23 morphologically diverse caves in the Tatra Mountains. Based on these studies, a development scheme of vadose cave passages has been proposed for the most common geological settings in the fold-andthrust-belt: (1) single-plain faults, (2) multiple fault cores, (3) bedding plane fractures and (4) hinge zones of recumbent folds. Results indicate that the dynamics of the massif (local gravity sliding in the nearby slope zone and regional stress fields), along with the structural pattern, influences the predisposition of structural and stratigraphic discontinuities to karst drainage. Constant tectonic stress fields affected the massif during the entire speleogenesis. This led to the rejuvenation of the same displacements in successive tectonic events, which resulted in promoting this reactivated structures in successive speleogenetic phases. Structures along which older cave levels had developed were also utilized later by vadose and phreatic drainage, leading to the intersection of the vadose passages with elevated paleo-phreatic cave levels. Independently, formation of entirely vadose caves, guided by the same group of weak and rejuvenated planes, was enabled. In the Tatras, the concentric and recumbent geometry of the main folds resulted in steep dipping of the bedding planes over a distance up to a few hundred meters which makes the bedding plane fractures subject to karst water circulation in these geologic and geodynamic settings.
\end{abstract}

Keywords: $\quad$ epigenic cave development, neotectonic, fold-and-thrust belt, Tatra Mts., Western Carpathians Received 24 March 2015; Revised 9 September 2015; Accepted 10 September 2015

Citation: Szczygieł J., 2015. Cave development in an uplifting fold-and-thrust belt: case study of the Tatra Mountains, Poland. International Journal of Speleology, 44 (3), 341-359. Tampa, FL (USA) ISSN 0392-6672 http://dx.doi.org/10.5038/1827-806X.44.3.10

\section{INTRODUCTION}

The role of tectonic structures in the development of caves has been studied from different angles, but the studies have focused primarily on the type and geometry of these structures (e.g., Čar \& Šebela, 1998; Tognini \& Bini, 2001; Baroň, 2002; Sauro et al., 2012) and their mutual spatial orientation, e.g., dip of bedding planes, width of fold, types of faults and fracture density (e.g., Ford \& Ewers, 1978; Palmer, 1991; Klimchouk \& Ford, 2000). This relationship has also been investigated in the Tatras (Grodzicki, 1970; Szczygieł \& Gaidzik, 2012; Szczygieł, 2013). Recently, researchers have been focusing on the ongoing tectonic evolution of the structure as well. Fissures, widened by neotectonic processes, are more susceptible to karstification than other structures (e.g., Faulkner, 2006; Sauro et al., 2013; Szczygiel et al., 2015). In some cases, when diagenesis results in lack of primary porosity, tectonics is the most effective way to open the initial fissure (secondary porosity) (Faulkner, 2006). On this basis, the Tectonic Inception hypothesis has been defined as "several separate but commonly related mechanisms, which release stress and arise from the isostatic rebound and surface erosion that occurred during deglaciation at the end of each glacial cycle, together with longertimescale plate tectonics, resulting in the formation of tectonic fractures in the upper (epikarstic) part of the limestone" (Faulkner, 2006). Later researches showed that the tectonic inception hypothesis refer to the whole karstic massif, the deep vadose and even the phreatic zones. However, this only applies to highly geodynamic settings like the Alps-Dinaric-Carpathian range or the Pyrenees, where caves development were concurrent with uplift and valley incision (Sauro et al., 2013; Tîrlă \& Vijulie, 2013; Pedrera et al., 2015, Szczygieł et al., 2015). Neotectonic processes may also affect the hydrogeological conditions through base-level regulation and forcing erosion, and valley incision (Piccini, 2011; Gabrovšek et al., 2014).

The aim of this study is to examine the role of structural geometry and neotectonic processes in 
the development of caves in high mountains during successive phases of their evolution. The structural guidance of cave passages is unquestionable, however, it is worth considering what makes the water flow along selected structures. Fold-and-thrust belts are typical structures in most orogenic belts controlled by compressional tectonics formed at plate boundaries (Poblet \& Lisle, 2011). From the structural point of view, the most common initial fissures in a fold and thrust belt include faults, fractures and folded strata, which result in steep bedding planes and bedding planes fractures. Faults, including thrusts, are generally perceived as single planes. In outcrop-scale, however, faults are much more complex and contain a fault core (including breccia or cataclasites), a damage zone (brittle) closer to the core and a drag zone (ductile) further from the core (see details in Fossen, 2010). Some fault zones are wider and composed of more than one core; this type is called a multiple fault zone (Faulkner et al., 2010). Within the folds, two specific zones can be distinguished: the contraction zone with the highest compression located closer to the core of the fold, where minor folds and faults are developed and the local extension zone located in the outer part of the fold where fractures perpendicular to the strata are formed (see details in Fossen, 2010). All of the above-mentioned types of structures were individually investigated in many case studies (Čar \& Šebela, 1998; Tognini \& Bini, 2001; Baroň, 2002). Nevertheless, fold-and-thrust belts give opportunity to examine all these structures in one karstic system. The Tatras may serve as a representative example for reasons such as: they constitute fold-and-thrust structures (Plašienka, 2003); a variety of tectonic structures are present there; the area is tectonically active (Perski, 2008); there are over 1,200 caves known in the Tatras with the longest one (Mesačný Tieň Cave, Slovakia) exceeding $30 \mathrm{~km}$ and the deepest one (Wielka Śnieżna Cave System, Poland) being $824 \mathrm{~m}$ deep. (Gradziński et al., 2009); three regional cave levels linked by steep passages may provide more information about several development phases of the Tatra caves, such as (epi)phreatic and vadose, including postglacial caves (Głazek et al., 1977). The study covers 23 caves (Supplemental Table 1) located in the Czerwone Wierchy massif, in the northern central part of the Tatra Mountains (Fig. 1). Distribution of selected caves is relatively uniform in the area of this massif (Fig. 2), and represents each geological subunit of the massif'.

\section{STUDY AREA}

\section{Geology}

The Tatras constitute the northernmost belt of the Central Western Carpathians (Fig. 1A), belonging to the Tatric-Fatric-Veporic nappe system, which is a basement-involved fold-and-thrust structure (Plašienka, 2003). The overthrust of the Tatra nappes took place in the Late Cretaceous (Kotański, 1961). Uplift of the Tatra block began in the Middle to Late Miocene from the depth of at least $5 \mathrm{~km}$ (Burchart, 1972; Král, 1977) and was rotated on a horizontal and latitudinal axis (Piotrowski, 1978; Bac-Moszaszwili,
1995; Jurewicz, 2005). A more rapid rate of uplift in the south led to uncovering of the crystalline basement in the southern and central part of the Tatra block. Duplex structures inclined towards the south have been rotated and currently dip towards the north (Jurewicz, 2003; 2005). The ascent and tilting of geological units composed of sedimentary rocks, mainly carbonates, gave rise to favorable conditions for the development of karst systems. Uplift of the Tatra block is still in progress, with geodetic surveys (Makowska \& Jaroszewski, 1987) and remote sensing (Perski, 2008) confirming the tilting of the block. In addition, earthquakes demonstrate tectonic activity of the region, with the most recent earthquake on November 30, 2004, at the north edge of Tatra Mts. and measured a magnitude of 4.7 (Wiejacz \& Dębski, 2009).

The Tatra Mts. are composed of a Paleozoic crystalline basement overlain by Mesozoic sedimentary rocks in the north and west (Nemčok et al., 1994; Fig. 1B). The sedimentary cover consists of the Tatric (autochthonous sedimentary cover and Czerwone Wierchy, Giewont, Široká nappes), Fatric (Križna nappe) and Hronic units (Choč nappe; Nemčok et al., 1994; Fig. 1B). The Czerwone Wierchy massif is composed of the following Tatric units: the autochthonous sedimentary cover, the Czerwone Wierchy Nappe (lower) and the Giewont Nappe (upper). The Giewont Nappe is located in the Czerwone Wierchy massif in the form of a tectonic klippe built of detached crystalline rocks and located in the summit areas (Kotański, 1963; Fig. 1C). The Mesozoic succession is similar in both autochthonous and Czerwone Wierchy units. At the base, the profile consists of Early Triassic sandstone. These deposits are covered by Early Triassic limestone and dolomite with shale interbeds (Kotański, 1961). The Middle Triassic is represented by partly bioturbated calcilutites interbedded with crinoidal limestone, bedded dolomite and dolomitized calcarenites (Jaglarz \& Rychliński, 2010). Upper Triassic sandstone, dolomites and sandy limestone occur only in the autochthonous unit along with Lower Jurassic sandstone and crinoidal limestone (Kotański, 1961). The Middle Jurassic penecordantly overlies the Middle Triassic and is represented by crinoidal limestone (Bajocian) and red nodular limestone (Bathonian; Lefeld et al., 1985). The carbonate succession of the Late Jurassic to Lower Cretaceous (Hauterivian) is represented by pinkish limestone (at the bottom) and thick-bedded limestone (Lefeld et al., 1985). Further up in the profile, Lower Cretaceous (Barremian, Aptian) thick-bedded reef limestone occur. At the top of the carbonate sequence there is glauconitic limestone, grey and pinkish limestone, and marls with sandstone intercalation of Albian - Cenomanian ages (Lefeld et al., 1985).

In general, the autochthonous Mesozoic succession dips gently towards the north between the crystalline basement and the nappes (Bac-Moszaszwili et al., 1984). In the Czerwone Wierchy massif section, the autochthonous series are partly folded (but not detached), whereas the parautochthon (Kotański, 1961; Fig.1C) is built of complex minor fold-and- 


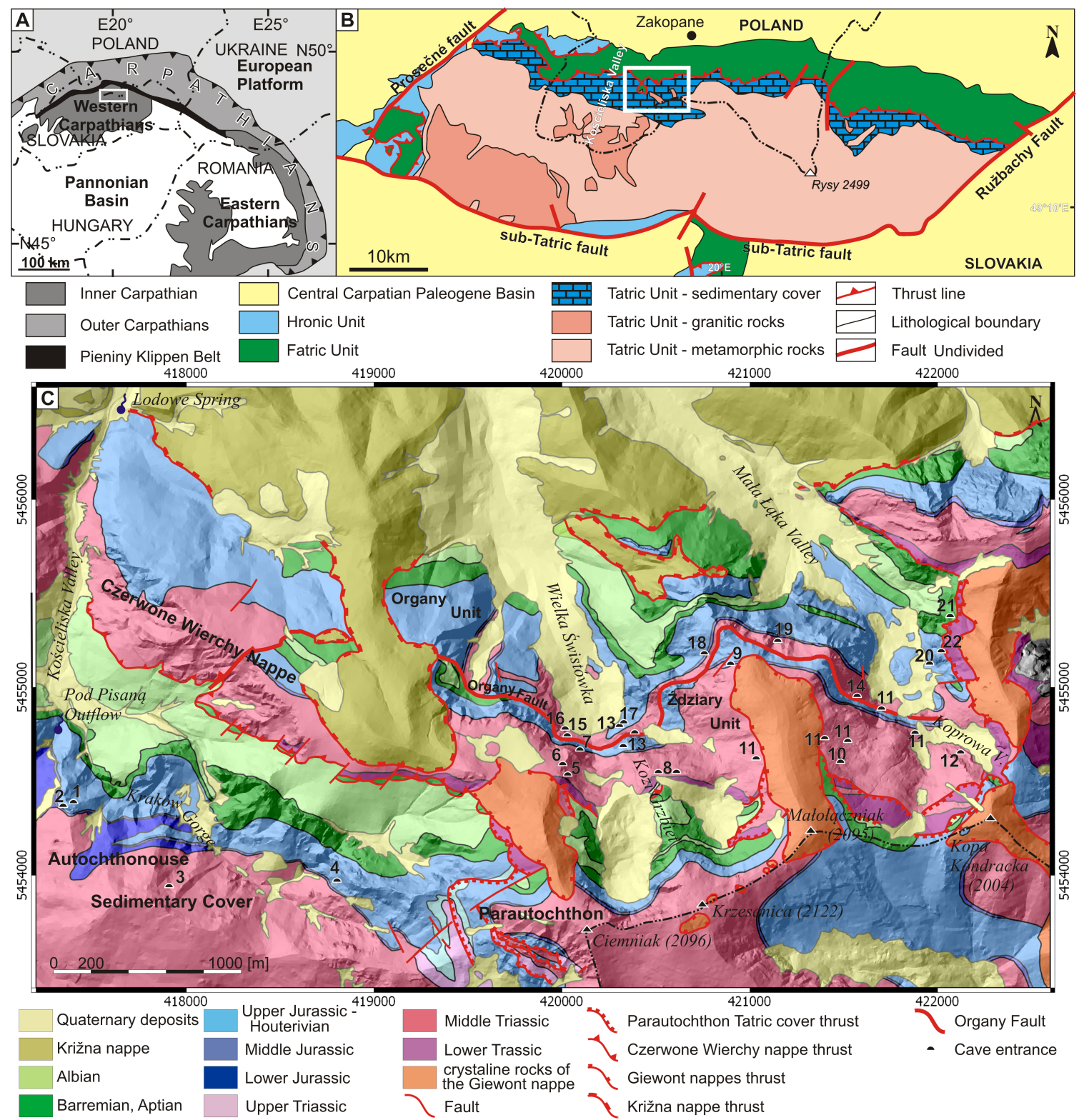

Fig. 1. Location of the study area: A) simplified geological sketch of the Carpathians with marked location of the Tatras (white rectangle); B) tectonic map of the Tatras (after Nemčok et al. 1994, modified) with location (white rectangle) of the Czerwone Wierchy massif; C) surface geological setting of study area (after Piotrowska et al., 2008; modified) and location of the investigated caves - cave numbers correspond to Supplemental Table 1.; $1 \mathrm{~km}$ grid; coordinates - WGS84 UTM zone 34N.

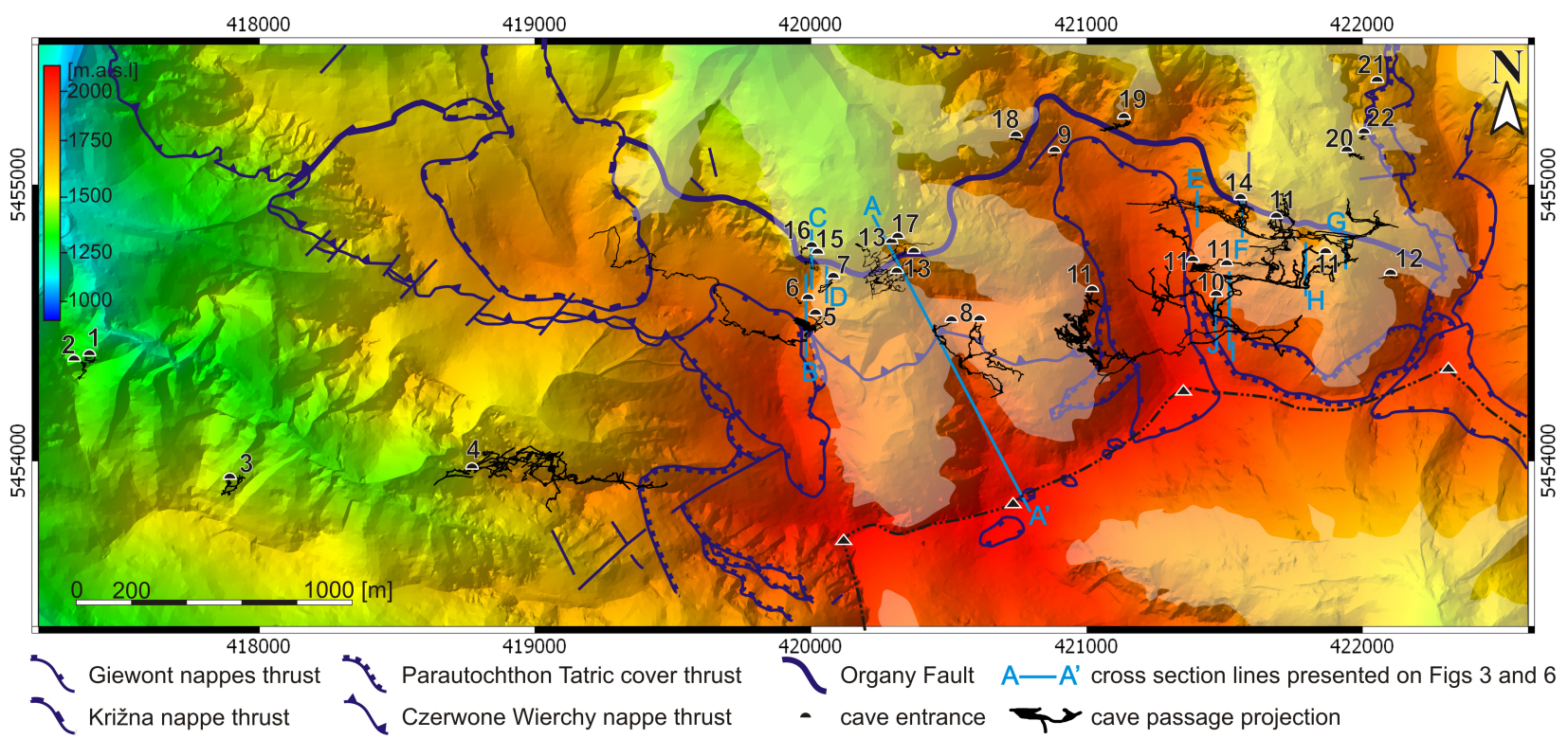

Fig. 2. Shaded digital elevation model with gradient elevation of the Czerwone Wierchy massif including: cave systems (cave numbers correspond to Supplemental Table 1.), tectonic setting (after Piotrowska et al., 2008; modified) and last glacial maximum cover (white semitransparent polygons; after Zasadni \& Kłapyta, 2014); 1 km grid; coordinates - WGS84 UTM zone 34N. 
thrust structures in the western portion of the Czerwone Wierchy massif (Rabowski, 1959; Kotański, 1961, 1963; Piotrowski, 1978; Szczygieł, 2012). On the northern slopes of the massif, the parautochthon is an inverted limb, gently inclined towards the south (Kotański, 1963; Bac-Moszaszwili et al., 1984; Fig. 3).

The Czerwone Wierchy Nappe is divided into two sub-units, the Organy (northern) and the Ździary (southern), which are separated by the Organy fault (Kotański, 1963, Figs. 1C, 3). The Organy unit is a chevron syncline, generally open to the north (Rabowski, 1959; Kotański, 1963) and recumbent, with its axial surface gently inclined towards the west (Grochocka-Rećko, 1963; Szczygieł, 2013; Fig. 3). The Ździary unit is also a syncline open to the north (Rabowski, 1959; Kotański, 1963) but the geometry is more concentric and the axial surface is gently inclined to the east in a western side, and to the south in central and eastern portion on the area (Piotrowski, 1978; Szczygieł et al., 2014; Fig. 3). The Organy Fault is quite uniform from the east to the west of the Czerwone Wierchy massif. The fault plane is steep and inclined towards the south (GrochockaRećko, 1963; Kotański, 1963; Szczygieł, 2013).

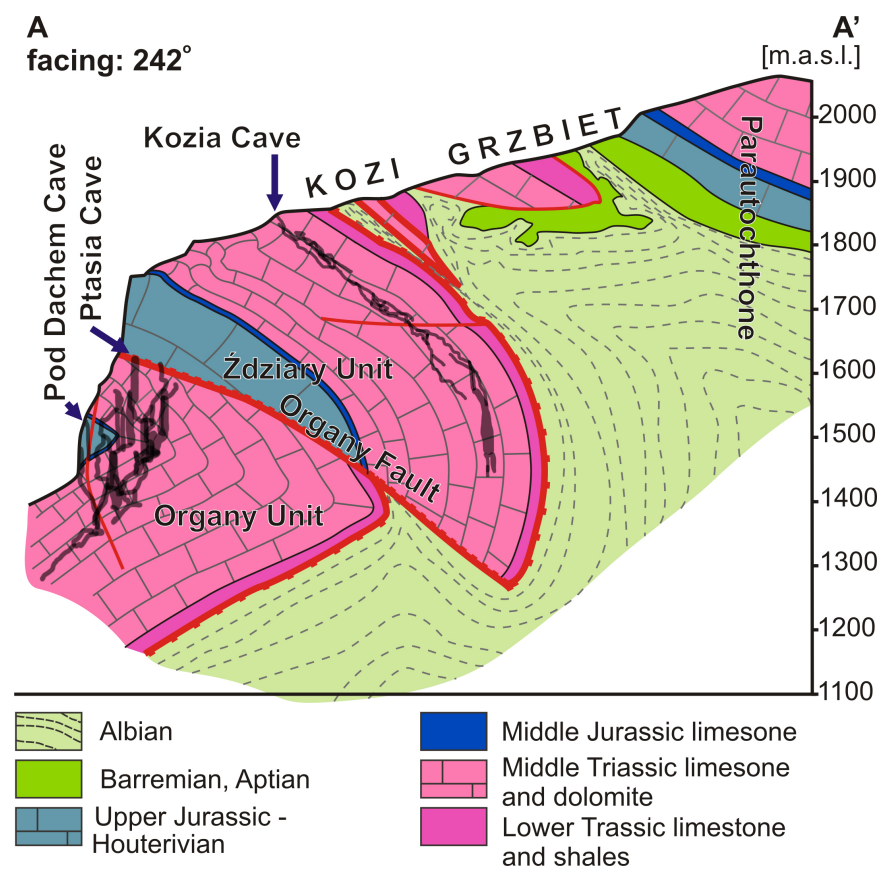

Fig. 3. Geological cross sections of the Czerwone Wierchy Fold-AndThrust structure based on Kotański (1961), Bac-Moszaszwili et al. (1984), Piotrowska et al. (2008) and own research. The cross section lines are shown in Fig. 2. Karst conduits are projected toward the direction of view. Notice how bedding planes of Ździary Unit guide the development of the vadose ramps and shafts.

\section{Karst morphology and hydrology}

The Czerwone Wierchy massif is the largest karst massif in the Tatras, with glaciokarst relief (Gadek $\&$ Litwin, 1999), and where most of the caves are located. The deepest caves drain the Czerwone Wierchy massif. Within the massif, there are two karst autogenic drainage systems. The first drains the south-western part of the massif, comprising the autochonous sedimentary cover, and drained by the Pod Pisana spring (1023 m a.s.1.; Rudnicki, 1967). The second, the Lodowe vauclusian spring, drains the largest karst system in the Tatra Mts. with the recharge area covering ca. $17 \mathrm{~km}^{2}$ of northern part of Czerwone Wierchy massif. Its mean discharge amounts to ca. 700 1/s (Barczyk, 2003).

The caves in the Tatras are deep, epigenic highmountain-type caves with two paleo-phreatic levels: older and poorly preserved (1550 - $1650 \mathrm{~m}$ a.s.1.) and younger (1300-1450 $\mathrm{m}$ a.s.1.) and one active (phreatic and epiphreatic passage) cave level (Rudnicki, 1967). These are intersected by steeply descending vadose conduits up to 824 deep, mostly proglacial (Głazek et al., 1977).

Initiation of the karst drainage probably started at the Late Miocene-Pliocene (Nowicki, 2003). The U-series dating of speleothems has revealed that the highest paleo-phreatic passages in the Czarna Cave (the highest cave level in the Lodowe spring system; Fig. 4) transitioned to the vadose zone no later than 1.2 Ma years ago (Nowicki, 2003). Gradziński \& Kicińska (2002) concluded that when Czarna Cave was forming, the modern valley network in the Czerwone Wierchy massif had already been established and flow directions were similar to the current ones. The lowest paleo-phreatic cave level in the Tatra Mts. located $\sim 100 \mathrm{~m}$ above the valley bottom was drained prior to ca. $120 \mathrm{ka}$ (data from the Zimna Cave; Fig. 4) indicating the maximum age of the current relief (Nowicki, 2003). Vadose erosion started simultaneously with phreatic one. Based on a map of the last glacial maximum in the Tatra Mts. (Zasadni \& Kłapyta, 2014), many entrances to vadose caves are located close to the last glacier's edge and only some are truncated shafts (Fig. 2). Many entrances are also connected with the boundary of the crystalline tectonic klippe in the summit regions of the massif (Fig. 1C). Overall, the location of most of the cave entrances is related to recent geomorphology, which indicates a very intensive vadose phase took place during the Late Pleistocene. However, features of earlier cave morphology may have been erased by subsequent erosion.

\section{METHODS}

Studies described hereare based on geomorphological observations and measurements of the spatial orientation of geological structures (bedding planes, fractures, meso-faults with accompanying shears and striations). Research was conducted in 23 caves and comprised almost 3,000 measurements. Detailed geometric structural analysis was performed. All collected tectonic data were statistically analyzed with the application of SpheriStat software (Pangaea Scientific). The orientations were summarized as structural diagrams in equal-area Lambert-Schmidt projections on the lower hemisphere. Rose diagrams illustrating strike directions were drawn.

To account for the structural guidance of entire caves, the comparison of tectonic structures (contour diagrams, rose diagrams, structural plans, geological cross sections) with cave pattern and passage morphology (field observations, maps, cross sections, 3-D survey data models) was supplemented by rose diagrams showing the distribution of conduit 


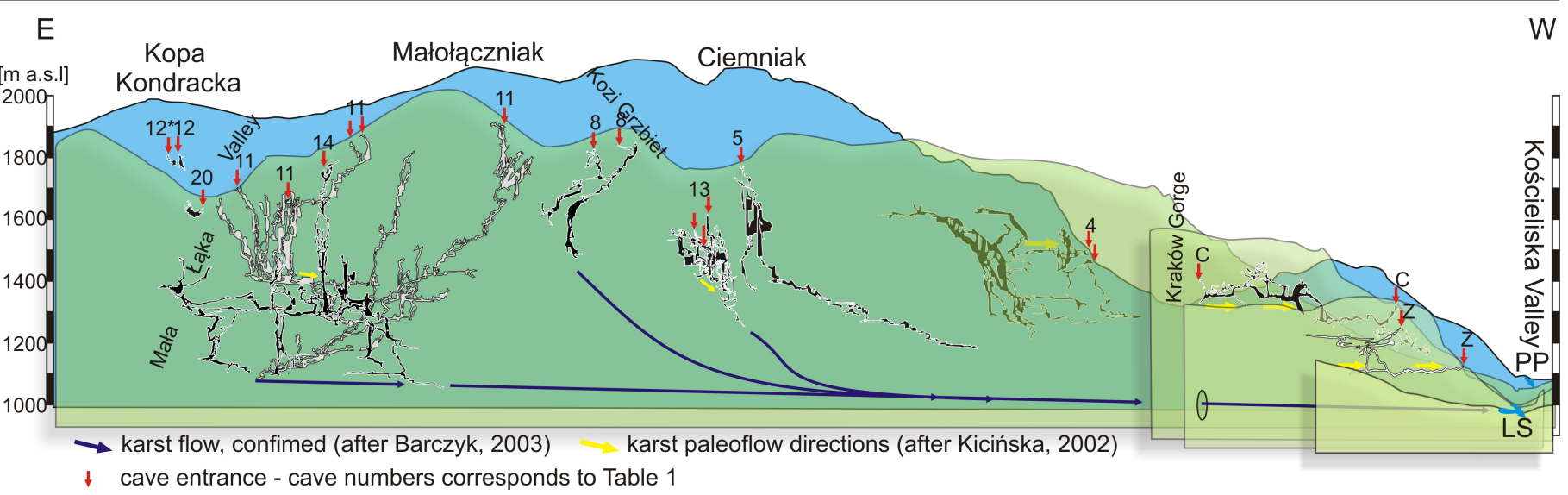

Fig. 4. Spatial distribution of geomorphology and cave cross sections of the Czerwone Wierchy massif with marked recent and paleo karst flow directions (after Szczygieł, 2015a; modified); note that in the figure are also Czarna and Zimna caves that have not been investigated, but previous research from those caves is discussed; C - Czarna Cave, Z - Zimna Cave, LS - Lodowe spring, PP - Pod Pisaną outflow.

directions. The rose diagrams are a compilation of conduit directions weighted by length. Survey data (measurement of passage orientation derived from a cave survey) with an inclination of $90^{\circ}$ were omitted because they have no azimuth. Due to the availability of data, survey shots from 15 caves were made. The entire analysis resulted in a simplified genetic model of cave development of the Czerwone Wierchy massif.

\section{CHARACTERISATION OF THE INVESTIGATED CAVES}

\section{Cave morphology and pattern}

Multilevel cave systems are distinguished by the intersection of their cave levels by a series of shafts and canyons (Fig. 4). The morphology and pattern of the cave levels point to their formation under phreatic and/ or epiphreatic conditions. Morphologically, passages are composed of horizontal or gently inclined rounded and lenticular tubes varying from 0.4 to $6 \mathrm{~m}$ width, often accompanied by scallops and solution pockets. Within the cave levels, there are some very steep but relatively short sections, which may have developed under phreatic conditions, forming a phreatic loop (Ford \& Ewers, 1978; Gradziński \& Kicińska, 2002). Phreatic or epiphreatic passage pattern is represented mostly by a main gallery with narrow branches. Single branches represent the bypasses (sensu Ford \& Ewers, 1978) located above the main gallery and have also been observed in Wysoka-Za Siedmiu Progami, Śnieżna Studnia, Psia, Wielka Śnieżna. Maze-type branches are characteristic for epiphreatic passages and are produced by periodic flooding (Palmer, 2007). Some of them form loops but there are also blind branches. Anastomotic mazes are less common.

Vertical and steep parts of the caves formed under vadose conditions are reflected in the following morphology features:

- shafts and chimneys up to $200 \mathrm{~m}$ depth - many of them are vertical cylindrical shaft (some up to $10 \mathrm{~m}$ diameter), lens-shaped vertical profiles and lenticular horizontal profiles of shafts are common as well, irregular horizontal profiles are less frequent but such shafts are deep (e.g., triangular, $\sim 130 \mathrm{~m}$ deep Koloseum shaft in Wysoka-Za Siedmiu Progami Cave);
- canyons - gently inclined, rectilinear, wide (1.5-5 m) passages even $\sim 50 \mathrm{~m}$ high (Fig. $5 \mathrm{~A}$ );

- meanders - narrow (narrowest place is $17 \mathrm{~cm}$ wide, average width is about $0.5 \mathrm{~m}$ ), sinusoidal in plan-view, often with "keyhole" profiles and solution notches;

- ramps - steep (but not vertical) passages whose dip is identical to dip of the bedding on a long distance (Fig. 5B); profiles can be similar to canyons or lenticular tubes; in a few cases ramps are roomy as a huge chamber, high but with steep and more or less planar floor wide to tens of meters.

Cascade and potholes are common in canyons and meanders. The pattern of the vadose caves and the vadose zone of multilevel systems are mostly branchwork, curvilinear or rarely rectilinear (sensu Palmer, 2007). Leakage and diversion of vadose flow are very common, and are expressed as parallel shafts or shortcuts in less steep passages. Fissure passages are present in both phreatic and vadose sections. All types of passages are locally remodeled by breakdowns. The most frequent morphologic features for each cave are presented in Supplemental Table 1.

\section{Structural setting}

Detailed tectonic data for each cave system are provided in App. 1. The text below contains a description of the most characteristic structures documented in the caves and their variability in the study area.

The general direction trend of bedding plane strikes is varies between ENE and ESE. This trend is disrupted in the fault zones (e.g., Lodowa Mułowa Cave; Fig. 6 cross section D-D', the Koprowa and Świstacza caves; Fig. 7). The orientation of beds was not documented in some caves (e.g., Szara Studnia, Lodowa Małołacka; App. 1) due to thick-bedded limestone and the lack of bedding plane regularity on the size of passages. Most bedding planes dip at angles of $40-70^{\circ}$, gradually changing to vertical in fold hinge zones (App. 1, Figs. 3, 4). Gently inclined strata have been documented only in the fault zones (Lodowa Mułowa, Lejbusiowa, Koprowa and Swistacza caves; Fig. 6 cross section D-D'; Fig. 5, App. 1). The main fold in the autochthonous sedimentary cover, 


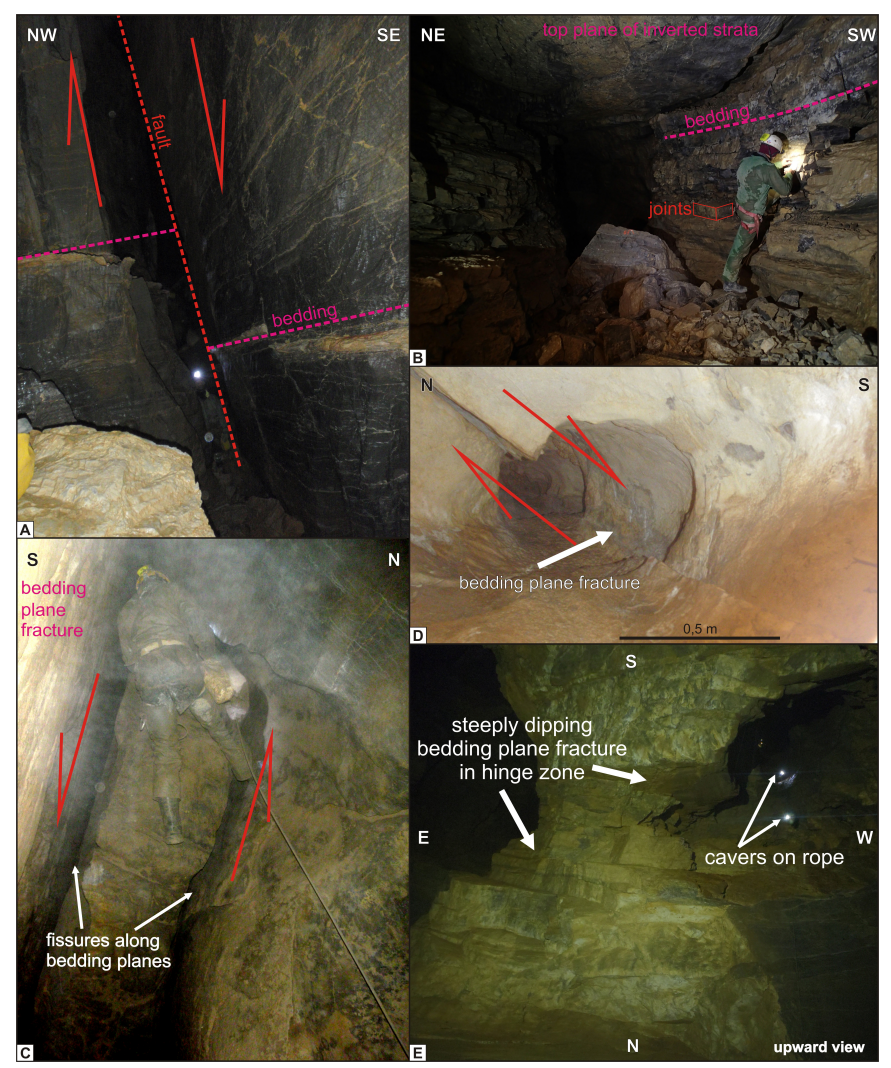

Fig. 5. Chosen tectonic features from studied caves: A) vadose canyon were formed along steep single-plane faults which is steeper than bedding, Ptasia Cave; B) vadose ramp developed on gently dipping strata, the direction of passage corresponds with dip direction of bedding, Kozia Cave (photo M. Golicz); C) vadose canyon formed along steeply dipping bedding planes, on the left bedding plane the stration is visible which indicate flexural slip or neotectonic movement, the Wielka Śnieżna Cave; D) a paleo-phreatic conduit developed along bedding plane, based on the same bedding plane the tectonic displacement took place and vadose ramps were formed, the Wielka Śnieżna Cave; E) the biggest cave chamber in Tatra's caves - The Fakro Chamber (the Mała w Mułowej Cave) developed in a hinge zone of main syncline of the Ździary Unit (see Fig. 6 cross section B-B'), steeply dipping bedding planes visible in ceiling of the chamber, cavers on rope to scale (photo M. Golicz).

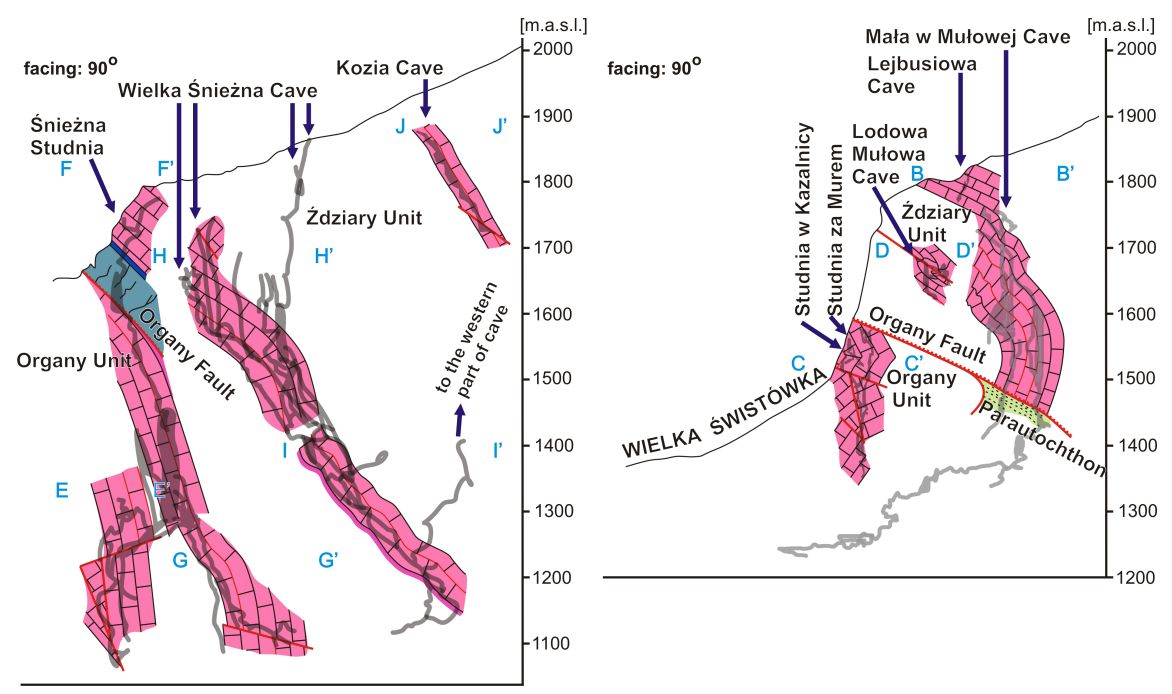

Fig. 6. Geological cross sections of the selected parts of caves based on field data and Szczygieł (2011, 2013). Compilation and projection on one cross section plane would make it impossible to determine the relationship between dip of structures and cave course, therefore a detailed cross sections for each fragments of the caves is presented. The traces are shown in Fig. 2; Karst conduits are projected toward the direction of view. Explanation of geology as in Fig. 3. Figs. 3, 6).

and inclined towards the east. Chevron geometry is a distinguishing feature of the main syncline in the Organy unit. In both synclines, the interlimb angle ranges from open to tight. Within the upper limbs, minor folds with gentle interlimb angles are often found (e.g., Ptasia Studnia, Mała w Mułowej Cave;

Due to erosion and corrosion, some fault features may have been weathered and therefore omitted during fieldwork. $\mathrm{N}-\mathrm{S}$ and $\mathrm{W}-\mathrm{E}$ strikes with steep to vertical dipping prevail within the faults. Some W-E striking faults are simply dislocations along bedding planes. Such faults dominate caves located in the Ździary and Organy units within the Middle Triassic carbonates (e.g., Kozia Cave, Małołącka Cave, Śnieżna Studnia). Some displacements along bedding planes are younger than cave passages, as is concluded from shifts in passage profile (Fig. 5D). Two generations of striation can be found on some of the flexural slip bedding planes, indicating multiple movements along these surfaces. Small folds related to bedding plane fractures have been documented as well, indicating that some flexural slip displacements occurred along beds when the rocks were more ductile, probably before exhumation of the Tatras.

Most of the faults are normal or normal-oblique. Reverse movements have been recorded infrequently (Groby Cave, Lodowa Mułowa, Mnichowa Studnia Wyżnia). Thrust plane of the Czerwone Wierchy nappe has been documented in the Mała w Mułowej Cave, where passages from a depth of $\sim 300 \mathrm{~m}$ to the bottom are gently inclined along the border of the mentioned nappe and autochthonous series (Szczygieł et al., 2014; Fig. 6). Many caves are located close to the Organy fault (Figs. 1, 2), however, passages cross this fault only in the Ptasia Studnia and the Śnieżna Studnia (Figs. 3, 6). In other cases, passages approaching the Organy fault are closed by breakdowns or filled by clastic sediments. Near the main thrusts, the network of minor faults is denser and multiple fault zones were formed (e.g., in the Koprowa Valley or near the Zośka-Zagonna Studnia; Fig. 2).

The most numerous structures are fractures. Dominant fractures strike at an angle of $30-50^{\circ}$ to the strike of the bedding. The second set consists of extensional fractures, which strike parallel to the bedding, but whose dip direction is perpendicular or oblique to the bedding. These two groups of fractures are common in all caves, however, Riedel shears are dominant in cave segments located near faults. Their orientation is dependent upon the fault with which they are associated. Within the shear zones, en-echelon fractures have been observed, but their calcite

documented in Wysoka -Za Siedmiu Progami Cave is a plunging inclined antiformal syncline (Szczygieł, 2012). Strata in the Ździary unit are arranged in concentric fold, ranging from recumbent to plunging, filling prevents making orientation measurements. Besides the above-mentioned sets, differently oriented fractures, whose population was too small to extract sets or systems, were measured. 


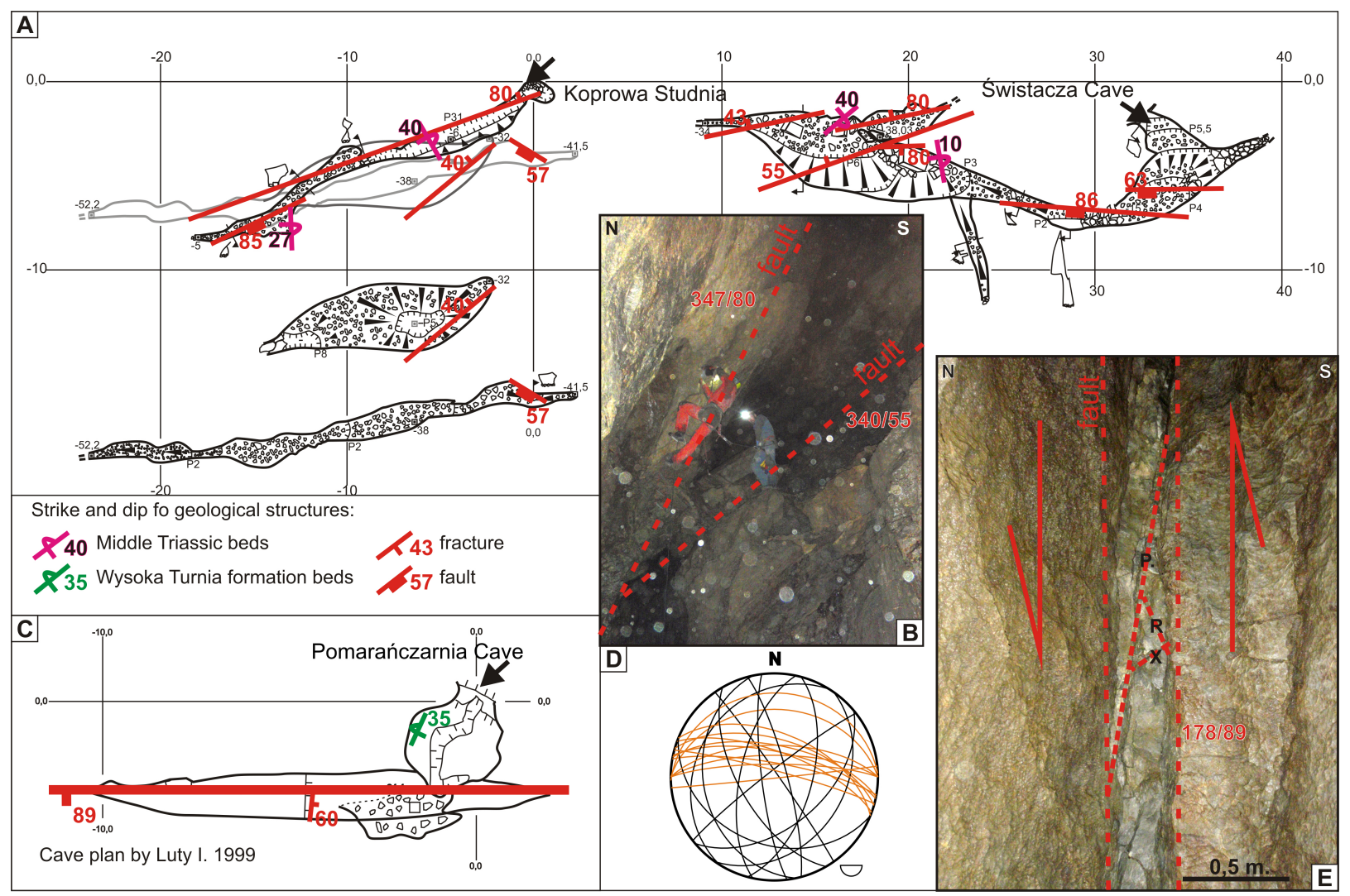

Fig. 7. A) Structural map of the Koprowa Studnia and the Świstacza caves, maps of both caves are projected in true distance; B) chamber in the western part of Świstacza Cave developed on conjugation of faults, both steeper than bedding; C) Structural map of the Pomarańczarnia Cave; D) orientation of fractures in the Pomarańczarnia Cave, orange circles correspond to fractures measured in the fault core along which the shaft were formed; E) the shaft in the Pomarańczarnia Cave developed along fault.

\section{STRUCTURAL GUIDANCE OF CAVES IN A FOLD-AND-THRUST BELT}

The fold-and-thrust belts may contain high variability in tectonic styles over a small area, which may affect cave patterns, as well as volume and morphology of passages. For example, in a small area in the Mała Łaka Valley, there are caves of extremely variable lengths and volumes, despite intensive exploration on both sides of the valley. The two deepest caves in the Tatras, Wielka Śnieżna Cave System and Śnieżna Studnia (Supplemental Table 1), are located on the western slope of the Mała Łaka Valley. Conversely, on the eastern side of the valley (Fig. 2), the largest cave barely exceeds $50 \mathrm{~m}$ in depth, with a length of $360 \mathrm{~m}$ (Lodowa Małołacka Cave). These slopes are only a few hundred meters apart (Fig. 1C). Moreover, they are built of the same tectonic units and lithostratigraphic formations, therefore the lithological control can be excluded. Additionally, this area was covered by the same glacier during the Pleistocene (Zasadni \& Kłapyta, 2014), therefore the climatic and hydrological conditions were also similar. Differences in the development of caves on both sides of the Mała Łaka Valley result from different local tectonic settings. The western part of the valley is composed of a complex of limestone steeply dipping towards the south, which is only locally deformed by minor folds and faults with small slip amplitudes (Fig. 6). As a result, water flowed along steep bedding planes without obstruction (Figs. 5C, D). On the eastern slope of the Mała Łaka Valley, beds dip gently $\left(20-40^{\circ}\right)$ but many steep and very steep fractures and faults occur, including the thrust of the Giewont Unit (Figs. 1C, 2). On the western side, the cave profile is slightly concave and strongly hierarchical, whereas on the eastern side it is slightly hierarchical. According to Audra et al. (2002), this indicates high fracture density on eastern side. The dense fracture network contributed to preventing the penetration of focused water flow into the massif, and thus inhibited the cave passages. A lot of exploratory work on the surface and in the cave is devoted to an attempt to find the entrance to the Śnieżna Studnia cave in its eastern part. Cross section of cave (cave no. 14 in Fig. 4) shows that the eastern part is recharged just from the region of Kopa Kondracka. However, these caves, which were explored in this area, and chimneys, which were explored in Śnieżna Studnia, are small, narrow and filled with rubble.

Comparison of morphological and structural features of 23 caves, highlighted by the examples given above, leads to the following interpretation. Caves can be divided into three groups according to the formation of vadose cave passages in different geological settings encountered in the fold-and-thrust belt; caves guided by (1) steep bedding planes or bedding plane fractures, (2) dense network of discontinuities, (3) single-plane fault (Fig. 8.). Phreatic passages rarely occur within investigated caves (Supplemental Table 1), thus data population is smaller and less representative. Therefore, the scheme presented in Fig. 8. does not include phreatic passages, of individual cases are described in the text.

It can be seen that some cave directions presented (App. 1) have no close relationship to fractures, faults and bedding plane strikes. This may be a result 
of conduit development at the conjunction of two structures or along the single inclined plane but oblique to strike. Another reason may be that the methods of surveying are not conducted in the middle of conduit.
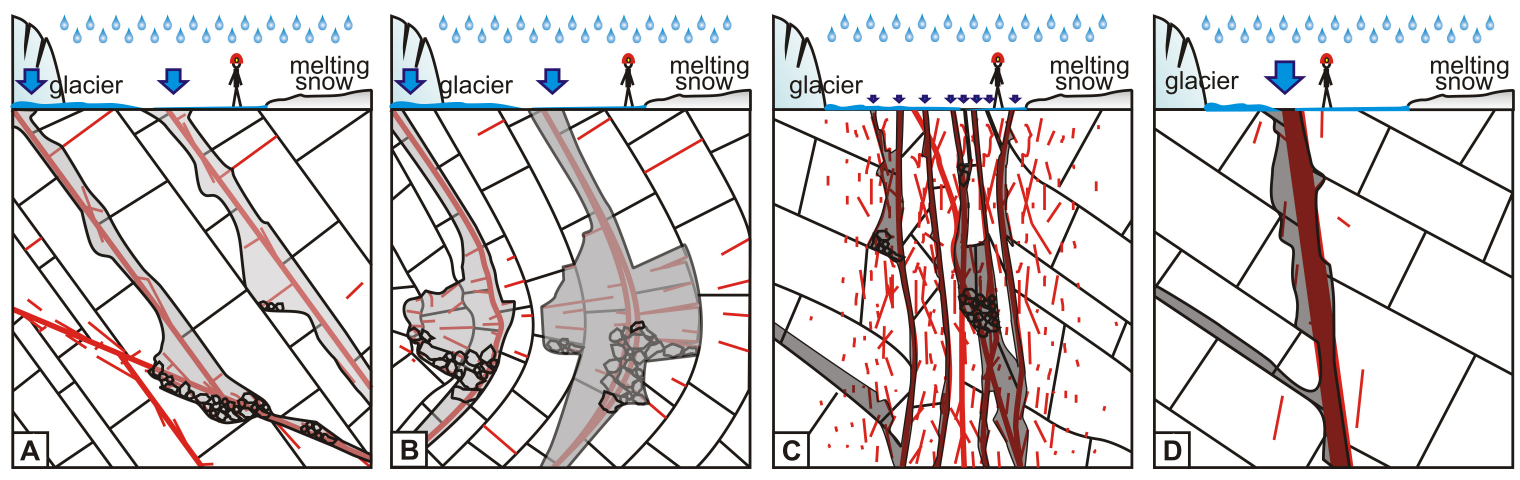

Fig. 8. Three kinds of tectonic guidance can be distinguished: cave inception may take place within the bedding plane fractures (A) and subtype of bedding plane fractures - fold hinge zone (B), multiple fault core (C), single-plane faults (D). Thick red lines - fault; thin red lines - fractures; black lines - bedding planes; grey polygons - cave cross section. Caver figure is posted to give the definition of a human accessible passage (a real cave); schematic rain, melting glacier and snow represents past and present water recharge sources in Tatra Mts.

\section{Caves guided by steep bedding planes or bedding plane fractures}

The first group consists of caves and cave passages that developed on steep bedding planes or bedding plane fractures (Fig. 8A). This group includes the longest and deepest caves in the study area (upper part of the Mała w Mułowej, lower part of the Ptasia Studnia Cave System, Kozia, Małołacka, Wielka Śnieżna Cave System, Śnieżna Studnia caves; Figs. 2-4). Many displacements along guiding bedding planes, older as well as younger than cave passages, were documented. This type of passage occurs in both paleo-phreatic (Fig. 5D) and vadose conduits (Fig. 5C). In the case of paleo-phreatic galleries, minor vertical amplitudes characterize passages. Cave patterns are represented mostly by single passages along the bedding strike; branching occurs rarely, but where it does, it often develops along the same structure. Passages formed in the vadose zone on bedding plane fractures are characterized by plunge and direction referring to the dip and dip direction of the bedding, respectively (Figs. 3, 6). If compared with boxes in rows $8,10,11,13$ in Appendix 1, it is clearly visible that cave-passage directions are perpendicular to bedding plane strike. Often, the general inclination of the cave systems is parallel to the bedding, but the direction of the individual passages is consistent with brittle structures, mostly joints and rarely faults (Fig. 5B). Ramps (see Cave morphology) are typical for passages guided by bedding planes as well as for canyons. Meanders are less frequent in the discussed setting, but if they are present, solution notches have developed along bedding planes. It is quite common for bedding plane fractures to be found in the ceiling; the passage morphology is then like "stairs beneath a faulted roof" (Audra et al., 2002). For example in the Małołacka Cave throughout its length, the ceiling of the cave is the bedding plane (Fig. 6, J-J'). The plunge and direction of the passage coincides perfectly with the dip and dip direction of the bedding, respectively. At the bottom of the cave, the passage crosses a gently inclined inactive fault, which drag zone probably contributed to breakdown.
The lithology, in which such type of caves develop, often include limestone and dolomitized calcarenites of the Middle Triassic age. It could be assumed that in the formation with dolomitic limestone interbeds, ramps are guided by "inception horizons" sensu Lowe \& Gunn (1997). However, these rocks are thin- and medium-bedded (a few $\mathrm{cm}$ to $\sim 40 \mathrm{~cm}$ ), hence even a small-range fracture in less soluble dolomitic limestone causes down cutting and the development of stair-step morphology. The only layer that could be identified as inception horizon is the Early Triassic limestone and dolomite with shale interbeds, but it guides only a few vadose passages in the lower part of Wielka Śnieżna.

Specific conditions exist in the hinge zones of main folds, where large-volume chambers or deep shafts have developed, depending on the geometry of the fold (Figs. 5E, 8B). Concentric folds have wider hinge zone outer from the fold core and narrow hinge zone closer to the core. Chevron folds have a comparatively narrow hinge zone regardless of the position relative to the core. In the Tatra Mts. main folds are recumbent, so the strata in hinge zones are vertical. Large chambers were formed in the narrow sections of bending, because the vertical distance of the more strongly deformed zone is shorter. Additionally, the contraction zone promotes the formation of breakdowns. Deep shafts are developed in the outer part of the concentric folds, where the bedding planes are steep over a long distance (Szczygiel, 2013).

\section{Caves guided by dense network of discontinuities}

The second group consists of caves developed in the dense network of discontinuities related to the major thrusts and other faults (Fig. 8C). These caves are shallow and short, a6nd small volumes characterize their passages. Cave pattern comprises anastomotic mazes or single passages with narrow curves in paleophreatic caves, and mostly rectilinear branch work in the vadose zone. A few caves contain chambers that developed due to collapse. The caves from this group comprise Lejbusiowa, Szara Studnia, Niebieska Studnia, Pomarańczarnia, Mnichowa Studnia Wyżnia, Lodowa Małołacka, Koprowa Studnia. Świstacza, 
Poszukiwaczy Skarbów, Groby (Fig. 2, Supplemental Table 1). Control of cave passage direction with respect to the fracture and fault networks is presented in rows 1, 12, 18, 20, 22 in Appendix 1.

Geological settings and morphology of the Koprowa Studnia and Swistacza caves (located in the eastern slope of Mała Łaka Valley), in relation to surrounding surface geology reflect high fracture density impact. These caves developed in a multiple fault zone, in vadose conditions in the Middle Triassic limestone, which belongs to the Ździary Unit (Fig. 1C). The guiding fault dips at angles of $60-80^{\circ}$ southward and is conjugated with a fault dipping at angles of $40-55^{\circ}$ towards the southeast (Fig. 7A). The chamber on bottom of the Swistacza Cave and the widest part of the entrance shaft in the Koprowa Studnia developed at the conjugation of the two fault planes. The cave passages intersect with stratification dipping at angles of $20-45^{\circ}$ towards the west and the northwest. Maps of both caves projected in true distance indicate that they constitute a single system connected by a fissure located between easternmost part of the Koprowa Studnia and westernmost passage in Swistacza, but they were once separated by breakdowns (Fig. 7A). The course of the caves is similar to the south slope of Koprowa Valley (Fig.1C). This could be indicative of the influence of a gravitational movement on the formation of initial fissures. The normal-slip movement of faults and commonly occurring autochthonous rubble and fragility documented in the caves supports this claim. The steps on fault planes are mineralized which proves that they are older than the caves, and possible gravity sliding was distributed along existing surfaces. Tectonic history of this area may be associated with the nearby Organy Fault along which the Koprowa Valley developed and with overthrust of the Giewont Nappe in the area of Kopa Kondracka peak (Fig. 2).

The small dimensions of those caves are the result of a high fracture density, indicated by dispersing inflows. The water flows into the massif along the steepest surface; in tectonically damaged areas, there is a dense net of steep planes, so water is able to penetrate many places, which represents entrances to Koprowa Studnia and Świtacza Cave spaced about 30 m. A dense network of discontinuities is also characterized by relatively short surfaces with narrower ranges, e.g., in comparison to the bedding planes. However, the water does not drain along the bedding planes, because they are less steep (e.g., Lejbusiowa Cave or Koprowa Studnia; see Appendix 1). Audra et al. (2002) noted that intense jointing allows the drainage area to be partitioned into many small basins. Consequently, many recharge points and many drainage possibilities hinder water flow and thus potentially leading to the development of a human-sized cave do not exist (Fig. 8C). Smaller catchment area is a smaller amount of groundwater that hence the smaller size of the cave and perhaps shorter activity. Additionally, permeability may be reduced by tectonic clay and flood loam, which contain less soluble minerals and fill the fractures (Fig. 9; Zupan Hajna, 1997). On the other hand, numerous big chambers or roomy passages are known in fault settings from other areas. For instance, in Postojna Cave (Šušteršič, 2006) and Spluga della Preta (Sauro et al., 2012) the biggest voids are located where the conduits break through the fault zones and related tectonic breccia, however in both cases the roomy parts are mature (Šušteršič, 2006; Sauro et al., 2012). The Koprowa Studnia and Świtacza caves are juvenile - the lack of absolute dating but location of the entrances with respect to the recent geomorphology suggests their formation during the last deglaciation; Fig. 2. Initially dissolved multiple fault zones are not solid enough to support channel formation, which leads to collapse. After subsequent enlargements channels may be stabilized (Šušteršič, 2002). The vadose parts of the caves in the Tatras were originated or remodeled during the Late Pleistocene, so are relatively young. Thus even if focused flow was present and a shaft or chamber developed, the highly fractured rock in the multiple fault core caused breakdowns or diffused flow within the encountered strongly fractured zone. The propensity towards collapsed (or undeveloped) passages in fault core zone is well identified in the Organy Fault which was previously proposed (Bac-Moszaszwili \& Nowicki, 2006) as one of the main structures were the largest caves in the Tatra could have developed. However, these studies were based on interpolation from surface data and not on fieldwork in the caves. Observations from the caves are contradictory, indicating rather an inverse relationship, whereby the Organy Fault often blocked the development of human-sized conduits (Figs. 4, 10B). For example, in the Śnieżna Studnia at ca. 1,600 $\mathrm{m}$ a.s.1., where the passage crosses the Organy Fault (Fig. 6 cross section F - F'), the transition was originally collapsed. The current excavated path through the rubble is very narrow, especially when compared to the surrounding passages. Also caves in

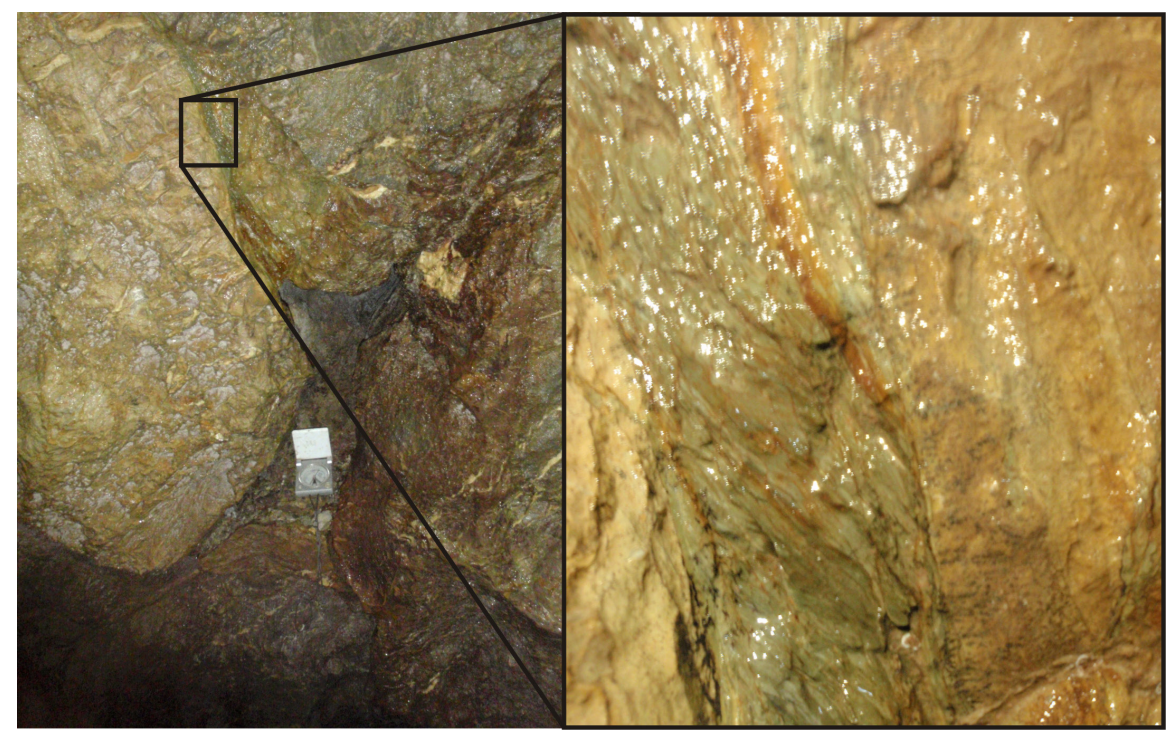

Fig. 9. Example of the fracture filled by tectonic clay. The right image is detail from the black rectangle on the left photo. 
cliffs above the Wielka Świstówka terminate above the fault, or start just below (Fig. 10B).

\section{Caves guided by single-plane fault}

The third group includes caves formed on the line of sub-vertical individual faults or on a conjugation of such faults (Fig. 8D). A relatively narrow drag zone is typical for these faults. Networks of related fractures or minor faults are rather poorly developed. These are mostly single-plane faults, rarely accompanied by tectonic breccia. It is also important that the plane of the fault is steeper than the one of the bedding. In other areas, it was documented that vadose passages are guided by steep faults within gently inclined strata (e.g., Plan et al., 2009; Sauro et al., 2013). Passages originating along a steep fault in the phreatic zone are characterized by relatively minor height differences (e.g., Kalacka Cave: see Szczygieł et al., 2015). Cave passages developed under vadose conditions are rectilinear and high (Fig. 5A). The morphology of these passages is often modified by breakdowns; however, forms resulting from water erosion and sediment transport are present (e.g., bends of meanders, scallops, flutes, autochthonous and allochthonous pebbles). Deep shafts were formed at the conjugation of vertical faults. Their distinguishing feature is irregular cross section. This group of caves comprises the eastern part of Wysoka - Za Siedmiu Progami (Fig. 4), the western part of the Wielka Śnieżna Cave System, Studnia w Kazalnicy, Zośka - Zagonna Studnia, Pod Dachem, partly Ptasia Studnia, Psia caves (Supplemental Table 1, Fig. 2). The selection of drainage routes is due to water flowing along the fault plane, which is steeper than the surrounding bedding planes. Crucially, the nature of the fault (single surface) enabled the water flux to concentrate. The fact that the fault intersects bedding planes makes lithology less important in the guidance of passages, because water can flow across less soluble carbonates. In such cases, lithology mostly affects the volume and shape of passages but not the cave pattern.

An example of a cave guided by single-plane faults but limited by multiple fault zone could be an aven-type cave, the Studnia w Kazalnicy, which developed in the vadose zone (Figs. 7, 10B). A nearentrance passage (up to $25 \mathrm{~m}$ deep) was formed along the bedding planes in the syncline hinge zone of the Organy unit. Below, shafts and meanders are guided by faults dipping at angles of $55-75^{\circ}$ towards the south and west; locally, the dip of meanders is related to the dip of stratification, but the course is identical with the fault. From a depth of $125 \mathrm{~m}$ to the bottom, the passages are arranged spirally, primarily along very steep faults, NW-SE fractures and locally bedding planes which are not steeper than $55^{\circ}$ (Szczygiel, 2011). The cave is limited upwards by the Organy Fault.

One special case involves caves formed along faults containing drag zones $20-50 \mathrm{~cm}$ wide. For example, Pomarańczarnia Cave developed along one fault (178/89; Fig. 7C). The guiding fault consists of two parallel slip surfaces and the narrow but highly fractured zone contained between them, whereas the outer walls are solid (Fig. 7D, E). In this case, the $30-\mathrm{cm}$-thick tectonic breccia zone impeded the flow and blocked the development of human-sized conduits. Field studies of passages originating in vadose zones show that single-plane faults without tectonic breccia constitute much better drainage routes (e.g., Studnia w Kazalnicy, Koloseum shaft in Wysoka-Za Siedmiu Progami Cave). Sauro et al. (2013) noticed similar relationships, but did not consider faults with tectonic breccia as inception features sensu stricto, as the passages did not develop along breccia. Nevertheless, such fault zones can supply water to surrounding structures.

\section{ASYMMETRIC UPLIFT AND NEOTECTONIC CONTROLS IN THE DEVELOPMENT OF THE KARST SYSTEMS}

Caves in the Tatras developed along the line of single-plane faults, multiple fault cores, bedding plane fractures and, of course, fractures related to these structures. However, structural setting is not the only geological factor determining cave development. Discontinuities are open and connected to a protoconduit network depending on their orientation to the present-day local stress field (Faulkner et al., 2010), which may facilitate flow in rocks with higher dissolution resistance. Common processes in the high mountain active orogens include extension through relaxation and gravity sliding. The impact of these phenomena on the development of caves depends on proximity to the surface (Sasowsky \& White, 1994; Faulkner, 2007), whereas the directions of stress tensors depends on morphology, i.e. principal minimum compressional axis is perpendicular to the slope (Szczygiel, 2015b). Therefore, they are local processes, while complex cave systems cover much bigger range reaching a few hundred meters or even a few $\mathrm{km}$. Apart from the influence of the morphology, the stress field is controlled by regional tectonics, e.g., transpressional settings (Sauro et al., 2013), or in the Tatra Mts. by the asymmetrical uplift (Králiková et al., 2014).

The hypothesis about the development of vertical caves as a result of relaxation and extension cracks parallel to the slopes was presented by Grodzicki (1970), who postulated dissolution as a negligible factor in cave formation, while the main factor would be related to a few meters displacements located below the nearest glacial cirque. Considering current geodynamics of the Tatras, such movements are highly unlikely. The number of solutional-erosional forms and their volume in Tatras' caves indicates that Grodzicki's assumptions (1970) were incorrect. According to Sasowsky \& White (1994) and Faulkner (2006, 2007), relaxing movements may affect small or shallow caves formed in the immediate vicinity of the glacier cirque but not deep complex cave systems. Nonetheless, even in cave passages located parallel to the cirque walls, there are karstic forms, developed by dissolution as demonstrated by Lauritzen (1986). An example of a cirque-wall-parallel cave from Tatras may be the Studnia za Murem. The entry shaft is 
separated from the cirque wall by $0.5 \mathrm{~m}$ thick bedrock. The shaft is characterized by an oval cross section pointing clearly to dissolution origin (Fig. 10C, D). From the cave map, the western part of the cave is parallel to the cirque (Fig. 10A), but the morphology of cave is characterized by lens-shaped shaft, meanders with potholes and, rarely, fissure passages. Thus, neotectonic processes or gravity sliding could have extended initial fissures. Nevertheless, dissolution and not extension due to relaxation was the main process behind the enlargements of passages. Also other caves in the study area which are similarly located could be partly initiated by the relaxation nearby the glacial circuses wall, including: Pod Dachem, Lodowa Mułowa, upper part of Studnia w Kazalnicy, W-E trending meanders and canyons in Ptasia Studnia.

T2 - Middle Triasic limestone and dolomite Rtf - Upper Jurassic - Hauterivian LM - Lodowa Mułowa Cave

SM - Studnia za Murem Cave

SK - Studnia w Kazalnicy Cave

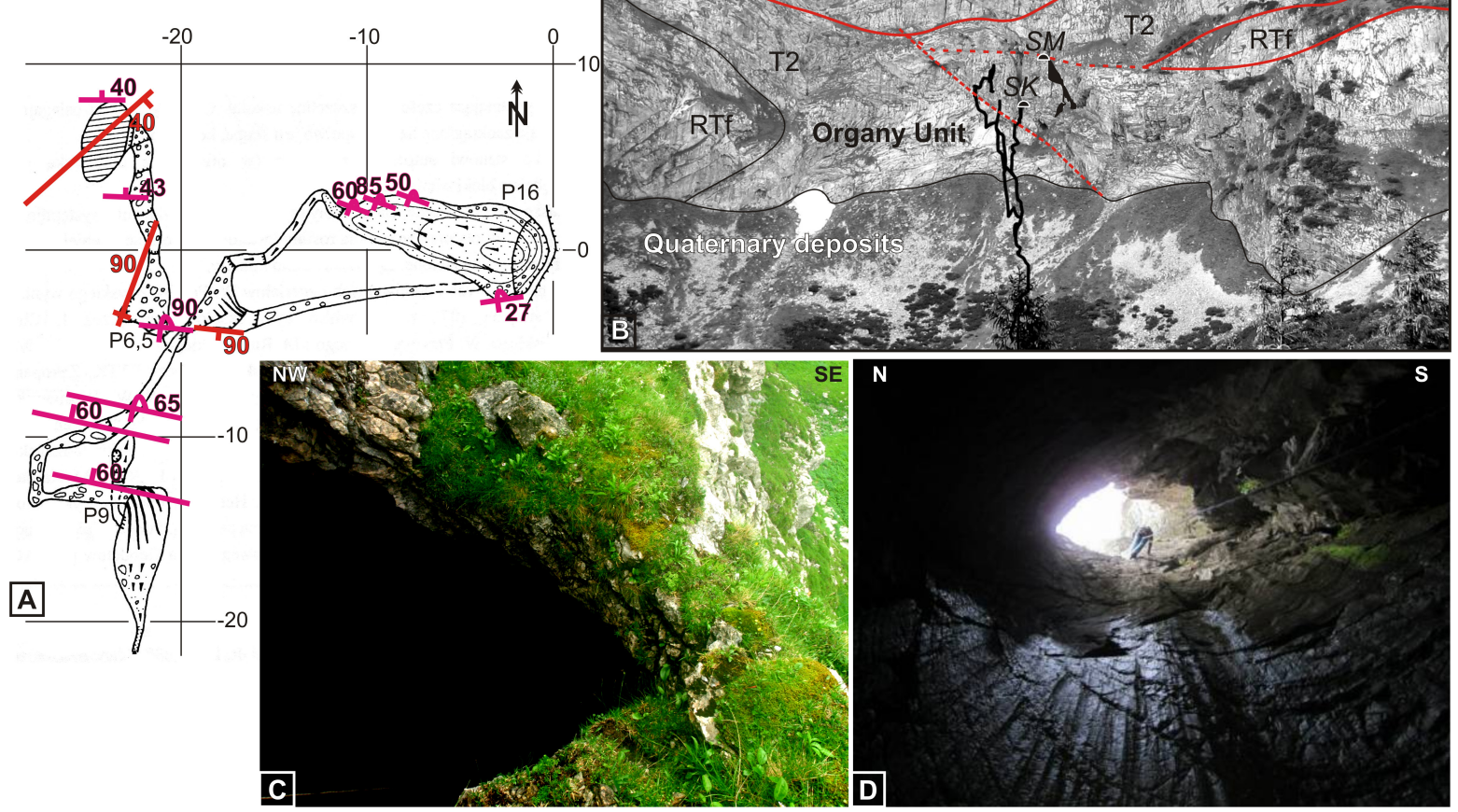

Fig. 10. A) Structural map of the Studnia za Murem Cave, cave map by Rutkowski (1972); B) Cliffs above the Wielka Świstówka; black line - stratigraphic boundary, red lines - faults, cross sections of caves are projected perpendicular to the photo; C) entrance shaft to Studnia za Murem Cave (to the left) separated from the cliff (to the right) by the thin (even less than $0.5 \mathrm{~m}$ ) rock wall, downward photo; D) entrance shaft to Studnia za Murem Cave with typical morphology of vadose shaft; view is upwards to the entrance at the center-top (photo downloaded from SBB).

Taking a more regional approach, there is a need to consider the uplift effect on speleogenesis. In previous studies, this issue has been regarded mainly as a regulator of base and water table levels (Palmer, 1991; Hauselman et al., 2003; Plan et al., 2009; Piccini, 2011; Audra \& Palmer 2013; Gabrovsek et al., 2014). Faulkner (2006) described its role in the process of opening the structure and allowing drainage of water as tectonic inception hypothesis. Sauro et al. (2013) suggested participation of tectonic inception in deep endokarst system development. In the investigated caves, displacements younger than passages are characterized by a gap approximately $3-5 \mathrm{~cm}$ wide and dip separation up to approximately $30 \mathrm{~cm}$ (Szczygieł, 2012, 2015b; Szczygieł et al., 2015). Crucially, many of these movements were triggered by asymmetrical uplift (Szczygieł, 2015b). All of neotectonic displacements reactivated existing structures: fractures and bedding planes, which in combination with two generations of striation on some bedding plane fractures, are consistent with the regularity with which tectonic stresses are distributed along the pre-existing plane of weakness (Fossen, 2010). In the Tatras, flexural slip along bedding planes took place probably as early as during the folding process at the Late Cretaceous (Plašienka, 2003). During the subsequent deformation, flexural slip surfaces could have been planes of weakness along which tectonic stresses were relaxed. The neotectonic deformation phase in the Tatra Mts. refers to the Late Pliocene-Quaternary, and tectonic stress field during that time was unchanged (Králiková et al., 2014). This period also corresponds to the time span of cave development in the Tatras (Nowicki, 2003).

If neotectonic movements used pre-existing structures, within a constant tectonic stress field during succeeding tectonic events (e.g., earthquakes), the stress should have been relaxed along the same structures. After each event, such structures are "weaker" and thus even more prone to reactivation. Therefore, faults rejuvenated in earlier phases of tectonic activity during the Quaternary were characterized by similar kinematics, sense and separation to recent faults. If so, the discontinuities 
were opened due to neotectonic processes over several hundred meters, e.g., a bedding plane fracture (Szczygieł, 2015b). Along such a structures, passages in the phreatic zone were formed, while speleogenesis of vadose conduits could be initiated independently along the same structure in the higher parts of the massif. Middle Triassic thin-bedded limestone with bedding planes as the most common planes of weakness, are particularly predisposed to this type of deformation. Filipponi et al. (2010) has interpreted bedding plane fractures as a one of three types of inception horizons. In turn, Sauro et al. (2013) noted that bedding plane fractures allow flow, because of some tectonic processes and not lithological differences. Therefore, bedding plane fractures are connected with tectonic inception sensu Faulkner (2006) and "the weakest" bedding planes reactivated as bedding plane fractures described above confirm this thesis.

The cycle of multi-level cave evolution during the Quaternary glaciations has been repeatedly described (e.g., Rudnicki, 1967, Głazek et al., 1977; Audra et al., 2002). The role of uplift in this cycle has been emphasized as well (Plan et al., 2009, Piccini, 2011). Audra \& Palmer (2013) summarizes these relationships: "Vertical cave pattern is mainly controlled by time, by the position of the aquifer (perched vs. dammed), by recharge type (regular vs. irregular), and by baselevel changes (lowering vs. rising)". All these factors explain the presence or absence of cave levels, depth of phreatic loops and average plunge trend of caves in vadose zones. However, they do not explain how the youngest vadose conduits, which evolved regardless of the cave levels located below, have developed along intersecting structures or linked simultanously different cave levels. Water that flows into the massif, e.g., $500 \mathrm{~m}$ higher, reaches precisely the passage belonging to the cave level, often cutting it continuing down to reach the underlying levels. Two scenarios are possible to explain the linking relationships between vadose passages and paleo-phreatic levels: 1) opening of fissures during or before the first phase of speleogenesis and their continuous karstification in the succeeding phase, 2) or multiphase speleogenesis related to multiphase neotectonic movements.

It is a widely accepted theory that cave levels are link with base level. Phreatic passages, which form cave levels, are transformed into epiphreatic and/or vadose zones as a result of base level lowering (e.g., Audra \& Palmer, 2013). The causes of such changes in mountainous environments is valley incision and this, in turn, is controlled by tectonic activity, mostly uplift and climate changes, for example glacial cycles that occurred during the Quaternary (Calvet et al., 2015). Based on sedimentological, geochronological, geomorphological and tectonic data mean rate of uplift on the Tatra Mts. can be an estimated at up to $1.0 \mathrm{~mm} / \mathrm{a}$, with a denudation rate of $0.2-0.5 \mathrm{~mm} / \mathrm{a}$ (Králiková et al., 2014 and reference there). This points to the importance of tectonic factors in base level changing in the Tatras orogen, at least as much as deglaciation. Based on that, a simplified genetic model for the caves in the Tatras is here proposed (Fig. 11). After asymmetrical exhumation of Tatra block, carbonates were exposed in northern portion of Tatras (the Pliocene? - Middle Pleistocene; Králiková et al., 2014). Cave levels originated along the strikes of the weakest planes in the rock (the most susceptible to water flow, i.e. tectonic inceptions); in many conduits, these original pathways were bedding planes moved by flexural slip or neotectonics (Fig. 11A). When the uplift led to descent of base level, phreatic galleries were elevated above the water table. Regional extension, which causes uplift, was expressed also as rejuvenation of faults operated under the valley's bottom, and facilitated the formation of phreatic loops. This rejuvenation resulted in the development of two cave levels along the same structure in succeeding speleogenesis phases, which are vertically separated for a few hundred meters (Fig. 11B). The possibility that guidance structures were open over the entire vertical range of current karst system

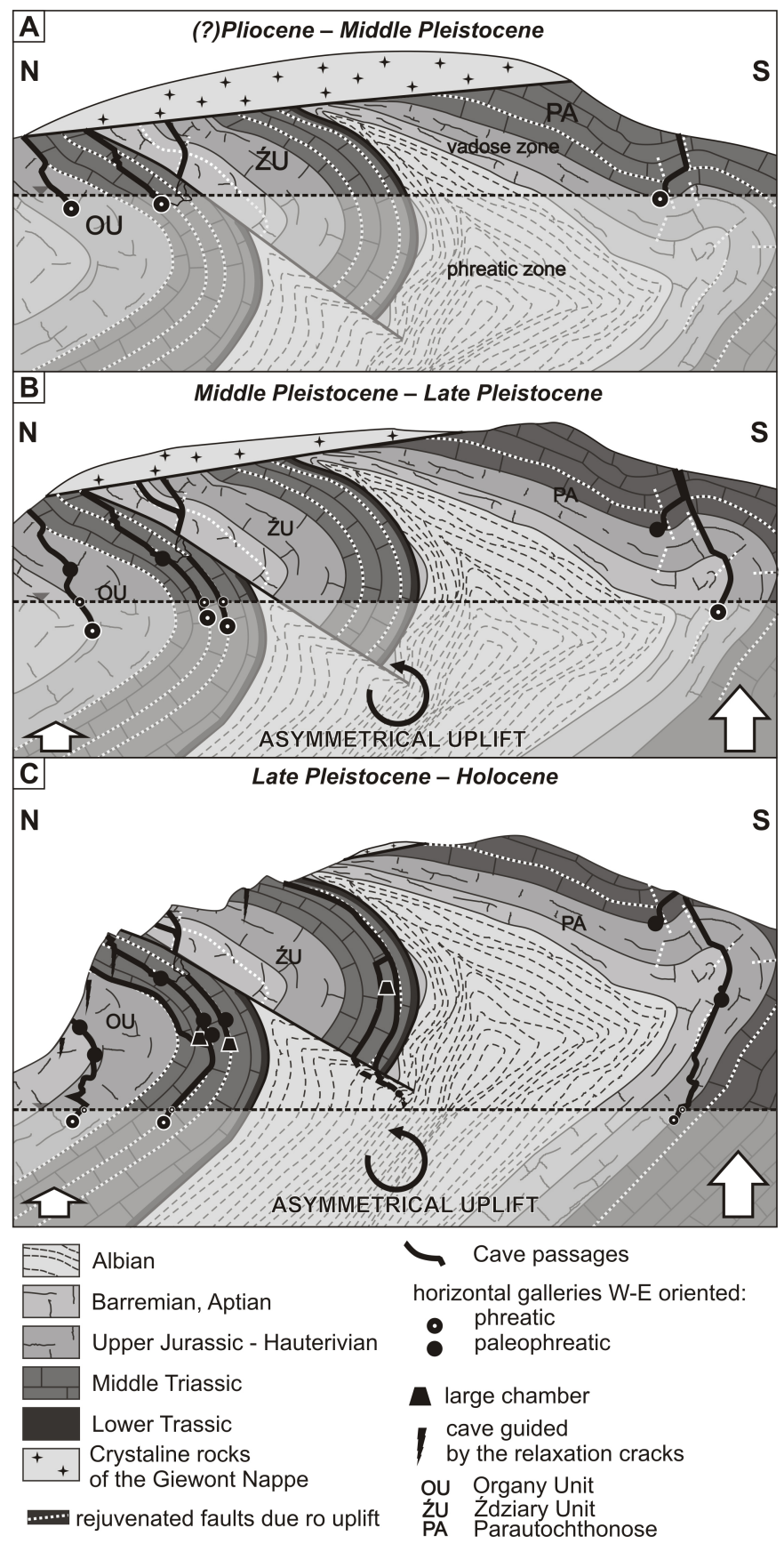

Fig. 11. Simplified genetic model of cave development of the Czerwone Wierchy massif. For explanation, see text; water table is represented schematically - in nature it is not so uniform. 
during the formation of the upper (the oldest) level is unlikely. In this scenario guidance structures in the Middle Pleistocene would had to have been widened approx. $600 \mathrm{~m}$ below the valleys' bottom, because that is the vertical distance between the highest and the lowest cave levels in Tatra Mts. It is more probable that extension operated during uplift, progressively widened fissures along with the exhumation of next portions of the orogen. Simultaneously, due to the deepening of the valleys, the relaxation of the massif resulted in some gravity sliding parallel to the ridges. The stresses were distributed in the first instance along existing planes (the weakest). Water drained along the same structures in the vadose zone and intersected the elevated paleo-phreatic cave levels to finally reach the current phreatic zone. This cycle in the Czerwone Wierchy massif was repeated at least twice (Fig. 11C). Three cave levels (including one active) and vadose conduits linking the levels were developed. Completely vadose caves could have been formed independently, as they are also guided by three main types of structures opened by regional extensional tectonic regime (e.g., the Mała w Mułowej Cave) or by relaxation caused by valley incision (e.g., the Studnia za Murem).

\section{CONCLUSIONS}

Three main types of structures are most prone to speleogenesis in the Tatra Mts.: single-plane faults, multiple fault cores and bedding plane fractures (Fig. 8). Furthermore, this research indicates that the structural setting was not the only tectonic factor influencing the predisposition of fissures towards the drainage of karstic water. The netotectonic activity of the massif, which determines regional stress field and consequently closes or opens fissures, thereby predisposing them to speleogenesis, seems to be equally important. The study results show that neotectonic processes, both older than and the contemporary to formation of caves, had a significant influence on the development of karst conduits. Although neotectonic movements probably involved the whole massif below the base level, it is unlikely that whole connected protoconduit network was established before the first phase of speleogenesis, especially when it concerns deep caves (a few hundred meters or more than a kilometer). When the base level lowering it is connected not only with erosion but also with uplift; structural settings are strongly affected by tectonic movements. Hence, the proto-conduit network was adjusted just before or simultaneously to the development of the conduits. This applies especially vadose zone where, in addition, the regional stress strongly influences the relaxation.

Gravity sliding, as well as regional extension, opened the existing structures, creating a network of initial fissures. However, the main factor behind the enlargement of cave passages (contradicting Grodzicki, 1970) was dissolution, not tectonics. It can be assumed that the recent neotectonic displacements reach a value of fault separations similar to that of pre-speleogenesis neotectonic faults. Therefore, they constituted prominent paths for water drainage. Bedding plane fractures, which were not deformed by faults, created the best conditions for drainage. In concentric and recumbent folds, bedding planes dip steeply, i.e. at the angle of $50-90^{\circ}$, over several hundred meters. This makes the bedding plane fractures the most prone pathway to groundwater circulation and thereby caves were formed in these geologic and geodynamic setting, i.e. an uplifting foldand-thrust belt.

\section{ACKNOWLEDGEMENTS}

I would like to thank Prof. Antoni Wójcik and Dr. Andrzej Tyc for supervising my research. I am very grateful to Francesco Sauro and two anonymous reviewers for improving the manuscript and encouraging discussion. This research would not have been possible without a permit from the Tatra National Park. I would like to thank my colleagues from caving clubs (46 cavers), for their support during fieldwork in caves, and especially Mateusz Golicz, Mateusz Kazimierczak, Tomasz Olczak and Piotr Sienkiewicz who have spent many days with me under the surface. Thank to Dr. Krzysztof Gaidzik for helpful discussions. I also wish to thank Patricia Kearney and Richard Battye for smoothing the English. This research was funded with a "Grant for Young Scientists" by the University of Silesia.

\section{REFERENCES}

Audra P., Quinif Y. \& Rochette P., 2002 - The genesis of the Tennengebirge karst and caves (Salzburg, Austria). Journal of Cave and Karst Studies, 64: 153-164.

Audra P. \& Palmer A.N., 2013 - The vertical dimension of karst: Controls of vertical cave pattern. In: J.F. Shroder (Editor-in-chief), Frumkin, A. (Volume Ed.). Treatise on Geomorphology, Vol. 6, Karst Geomorphology, San Diego, Academic Press, p. 186-206.

Bac-Moszaszwili M., 1995 - Diversity of Neogene and Quaternary tectonic movements in Tatra Mountains. Folia Quaternaria, 66: 131-144.

Bac-Moszaszwili M., Jaroszewski W. \& Passendorfer E., 1984 - On the tectonics of Czerwone Wierchy and Giewont area in the Tatra Mts. (Poland). Annales Societatis Geologorum Poloniae, 52: 67-88 (In Polish, English summary).

Bac-Moszaszwili M. \& Nowicki T., 2006 - Remarks on caves development in the Czerwone Wierchy Nappe in the Tatra Mts. Przeglad Geologiczny, 54 (1): 56-60. (In Polish, English summary)

Barczyk, G., 2003 - Karst and vaucluse springs from the Polish Tatra Mts. Results of long-term stationary investigations. Acta Carsologica, 32 (1): 145-155.

Baroň I., 2002 - Speleogenesis along sub-vertical joints: A model of plateau karst shaft development: A case study: the Dolny Vrch Plateau ( Slovak Republic). Cave \& Karst Science, 29: 5-12.

Burchart J., 1972 - Fission-track age determinations of accessory apatite from Tatra Mts., Poland. Earth Planetary Science Letter, 15: 418-422. http://dx.doi.org/10.1016/0012-821X(72)90041-6

Calvet M., Gunnell Y., Braucher R., Hez G., Bourlès D., Guillou V. \& Delmas M., 2015 -Cave levels as a proxy for measuring post-orogenic uplift: Evidence from cosmogenic dating of alluvium-filled caves in the French Pyrenees. Geomorphology, 246: 617-633. http://dx.doi.org/10.1016/j.geomorph.2015.07.013 
Čar J. \& Šebela S., 1998 - Bedding planes, moved bedding planes, connective fissures and horizontal cave passages (examples from Postojnska Jama Cave). Acta Carsologica, 27 (2): 75-95.

CBDG - The national geological database. Polish Geological Institute - National Research Institute. http://geoportal.pgi.gov.pl/jaskinie-pub/jaskinie [accessed: March 20, 2015]

Faulkner T., 2006 - Tectonic inception in caledonide marbles. Acta Carsologica, 35 (1): 7-21. http://dx.doi.org/10.3986/ac.v35i1.239

Faulkner T., 2007 - The one-eighth relationship that constrains deglacial seismicity and cave development in caledonide marbles. Acta Carsologica, 36 (2): 195-202.

Faulkner D.R., Jackson C.A.L., Lunn R.J., Schlische R.W., Shipton Z.K., Wibberley C.A.J. \& Withjack M.O., 2010 - A review of recent developments concerning the structure, mechanics and fluid flow properties of fault zones. Journal of Structural Geology, 32: 1557-1575. http://dx.doi.org/10.1016/j.jsg.2010.06.009

Filipponi M., Jeannin P.-Y. \& Tacher L., 2010 Understanding cave genesis along favourable bedding planes. The role of the primary rock permeability. Zeitschrift für Geomorphologie, 54 (2): 91-114. http://dx.doi.org/10.1127/0372-8854/2010/ 0054S2-0006

Ford D.C. \& Ewers R., 1978 - The development of limestone cave systems in the dimensions of length and depth. Canadian Journal of Earth Science, 15: 1783-1798. http://dx.doi.org/10.1139/e78-186

Fossen H., 2010 - Structural geology. Cambridge University Press, New York, 481 p.

http://dx.doi.org/10.1017/CBO9780511777806

Gabrovšek F., Häuselmann P. \& Audra P., 2014 "Looping caves" versus "water table caves": The role of base-level changes and recharge variations in cave development. Geomorphology, 204: 683-691.

http://dx.doi.org/10.1016/j.geomorph.2013.09.016

Gadek B. \& Litwin L., 1999- Glaciokarst of subalpine and alpine zone of the Mała Łaka Valley, Tatra Mts., Poland. Acta Carsologica, 28 (1): 71-86.

Głazek J., Rudnicki J. \& Szynkiewicz A., 1977 - Proglacial caves - a special genetic type of caves. In: Ford T.D. (Ed.), Proceedings of the $7^{\text {th }}$ International Congress of Speleology, Sheffield, 215-217.

Gradziński M., Hercman H., Kicińska D., Barczyk G., Bella P. \& Holubek P., 2009 - Karst in the Tatra Mountains - developments of knowledge in the last thirty years. Przeglad Geologiczny, 57 (8): 674-684. (In Polish, English summary)

Gradziński M. \& Kicińska D., 2002 - Morphology of Czarna Cave and its significance form the geomorphic evolution of the Kościeliska Valley (Western Tatra Mts.). Annales Societatis Geologorum Poloniae, 72: 255-262.

Grochocka-Rećko K., 1963 - Geology of the Wyżnia Świstówka (Western Tatra). Acta Geologica Polonica, 13 (2): 239-279. (In Polish, English summary)

Grodzicki J., 1970 - Le role de la tectonique dans le genčse des cavernes karstiques du massif Czerwone Wierchy (les Tatres Occidentales). Speleologia, 5: 3348. (In Polish, French summary)

Häuselmann P., Jeannin P.-Y. \& Monbaron M., 2003 - Role of epiphreatic flow and soutirages in conduit morphogenesis: the Barenschacht example (BE, Switzerland). Zeitschrift für Geomorphologie, 47: 171-190.

Jaglarz P. \& Rychliński T., 2010 - Remarks on nomenclature of Triassic carbonate rocks from the Tatra Mts. Przegląd Geologiczny, 58 (4): 327-334. (In Polish, English summary)
Jurewicz E., 2003 - Multistage evolution of the shear zone at the base on The Giewont Unit, Tatra Mountains. Geologica Carpathica, 54 (5): 337-351.

Jurewicz E., 2005 - Geodynamic evolution of the Tatra Mts . and the Pieniny Klippen Belt (Western Carpathians): problems and comments. Acta Geologica Polonica, 55 (3): 295-338.

Kicińska D., 2002 - Kenozoiczna ewolucja cyrkulacji wód krasowych w Tatrach Zachodnich. Unpublished PhD. Thesis, Adam Mickiewicz University, Poznań, 103 pp. (In Polish).

Klimchouk A. \& Ford D., 2000 - Lithologic and structural controls of dissolutional cave development. In: Klimchouk A., Ford D.C., Palmer A.N. \& Dreybrodt W. (Eds.), Speleogenesis. Evolution of karst aquifers. National Speleological Society, Huntsville, p. 54-64.

Kotański Z., 1961 - Tectogenes et reconstitution de la paleogeogrphie de la zona haut-tatrique dans les Tatras. Acta Geologica Polonica, 11 (2): 187-396. (In Polish, French summary)

Kotańsk Z., 1963 - New elements in the structure of the Czerwonych Wierchow massif. Acta Geologica Polonica, 13 (2): 149-181. (In Polish, English summary)

Král J., 1977 - Fission track ages of apatites from some granitoid rocks in West Carpathians. Geologica Carpathica, 28: 269-276.

Králiková S., Vojtko R., Sliva U., Minár J., Fügenschuh B., Kováč M. \& Hók J., 2014 - Cretaceous Quaternary tectonic evolution of the Tatra Mts. (Western Carpathians): constraints from structural, sedimentary, geomorphological, and fission track data. Geologica Carpathica 65 (4): 307-326.

http://dx.doi.org/10.2478/geoca-2014-0021

Lauritzen S.-E., 1986 - Kvithola at Fauske, northern Norway: an example of ice-contact speleogenesis. Norsk Geologisk Tidsskrift, 66: 153-161.

Lefeld J., Gaździcki A., Iwanow A., Krajewski K. \& Wojcik K., 1985 - Jurassic and Cretaceous lithostratigraphic units of the Tatra Mountains. Studia Geologica Polonica, 84: 1-93.

Lowe D.J. \& Gunn J., 1997 - Carbonate speleogenesis: An Inception Horizon Hypothesis. Acta Carsologica, 26 (2): 457-488.

Luty I., 1999 - Map of the Pomaranczarnia Cave. http:// geoportal.pgi.gov.pl/jaskinie-pub/jaskinie/ [accessed: March 20, 2015]

Makowska A. \& Jaroszewski W., 1987 - O współczesnych ruchach pionowych $w$ Tatrach i na Podhalu. Przegląd Geologiczny, 35: 506-512. (in Polish).

Nemčok J., Bezák V., Biely A., Gorek A., Gross P., Halouzka R., Janák M., Kahan Š., Kotański Z., Lefeld J., Mello J., Reichwalder P., Raczkowski W., Roniewicz P., Ryka W., Wieczorek J. \& Zelman J., 1994 Geological map of the Tatra Mountains. MŽP SR, GÚDŠ, Bratislava.

Nowicki T., 2003 - Ewolucja jaskiń systemu Lodowego Źródła w świetle datowania nacieków jaskiniowych metoda uranowo-torowa. Unpublished Ph.D. Thesis, Polish Academy of Sciences, 145 p. (in Polish).

Palmer A.N., 1991 - Origin and morphology of limestone caves. Geological Society of America Bulletin, 103: 1-21. http://dx.doi.org/10.1130/0016-7606(1991)103 $\leq 0001$ :OAMOLC $>2.3 . \mathrm{CO} ; 2$

Palmer A.N., 2007 - Cave geology. Cave Books, Dayton, $454 \mathrm{p}$.

Pangea Scientific, 1990 - SpheriStat, Version 2.2

Perski Z., 2008 - Recent tectonic activity of the Tatra Mts. and Podhale (Poland) studied by InSAR and PSInSAR. Przegląd Geologiczny, 56 (12): 1082-1086. (In Polish, English summary) 
Pedrera A., Luque-Espinar J.A., Martos-Rosillo S., PardoIgúzquiza E., Durán-Valsero J.J., Martínez-Moreno F. \& Guardiola-Albert C., 2015 - Structural controls on karstic conduits in a collisional orogen (Sierra de las Nieves, Betic Cordillera, S Spain). Geomorphology, 238: 15-26. http://dx.doi.org/10.1016/j.geomorph.2015.02.008

Piccini L., 2011 - Speleogenesis in highly geodynamic contexts: The quaternary evolution of Monte Corchia multi-level karst system (Alpi Apuane, Italy). Geomorphology, 134: 49-61.

http://dx.doi.org/10.1016/j.geomorph.2011.06.005

Piotrowska K., Cymerman Z. \& Raczkowski W., 2008 - Geological map of Polish Tatra Mts. scale 1:10.000, Czerwone Wierchy sheet - surfaces geological map. Polish Geological Institute, Warsaw.

Piotrowski J., 1978 - Mesostructural analysis of the main tectonic units of the Tatra Mountains. Studia Geologica Polonica, 55: 1-80. (In Polish, English summary)

Poblet J. \& Lisle R., 2011 - Kinematic evolution and structural styles of fold-and-thrust belts. In: Poblet J. $\&$ Lisle R. (Eds.), Kinematic evolution and structural styles of fold-and-thrust belts. The Geological Society, London, p. 1-25.

http://dx.doi.org/10.1144/sp349.1

Plašienka D., 2003 - Development of basement-involved fold and thrust structures exemplified by the TatricFatric-Veporic nappe system of the Western Carpathians (Slovakia). Geodinamica Acta, 16: 21-38. http://dx.doi.org/10.1016/S0985-3111(02)00003-7

Plan L., Filipponi M., Behm M., Seebacher R. \& Jeutter P., 2009 - Constraints on alpine speleogenesis from cave morphology - A case study from the eastern Totes Gebirge (Northern Calcareous Alps , Austria). Geomorphology, 106: 118-129.

http://dx.doi.org/10.1016/j.geomorph.2008.09.011

Rabowski F., 1959 - High-tatric series in Western Tatra. Prace Instutytu Geologicznego 27, Warsaw, 166 p. (In Polish, English summary).

Rudnicki J., 1967 - Origin and age of the Western Tatra caverns. Acta Geologica Polonica, 17 (4): 521-594. (In Polish, English summary)

Rutkowski M., 1972 - Map of the Studnia za Murem Cave. http://geoportal.pgi.gov.pl/jaskinie-pub/jaskinie/ [accessed: March 20, 2015]

Sasowsky I.D. \& White W.B., 1994 - The role of stress release fracturing in a development of cavenous porosity in carbonate aquifers. Water Resources Research, 30 (12): 3523-3530.

http://dx.doi.org/10.1029/94WR01727

Sauro F., Piccini L., Menichetti M., Artoni A. \& Migliorini E., 2012 - Lithological and structural guidance on speleogenesis in Spluga della Preta cave, Lessini Mountains (Veneto, Italy). Geografia Fisica e Dinammica Quaternaria, 35: 167-176.

Sauro F., Zampieri D. \& Filipponi M., 2013 - Development of a deep karst system within a transpressional structure of the Dolomites in north-east Italy. Geomorphology, 184: 51-63.

http://dx.doi.org/10.1016/j.geomorph.2012.11.014

SBB - Studnia za Murem cave exploration report. Bielsko-Biała Caving Club.

Szczygieł J., 2011 - Geology of the Studnia w Kazalnicy Cave in the Western Tatra Mts. Acta Geographica Silesiana, 1. Special Issue: 73-77. (In Polish, English summary)
Szczygieł J., 2012 - Subsurface geological structure of upper part of the Krakow Gorge based on studies of the Wysoka - Za Siedmiu Progami Cave,West Tatra Mts. Przegląd Geologiczny, 60 (4): 232-238. (In Polish, English summary)

Szczygieł J., 2013 - The role of fold-and-thrust structure in the large shafts and chambers development: case study of the Polish Tatra Mts. In: Filippi M. \& Bosak P. (Eds.), Proceedings of $16^{\text {th }}$ International Congress of Speleology. International Union of Speleology, Brno, 3: 137-143.

Szczygieł J., 2015a - Spatial distribution of caves and topography of the Czerwone Wierchy massif. In: Dabrowska K. \& Guzik M. (Eds.), Atlas of the Tatra Mts. Abiotic Nature. Tatra National Park, Zakopane, In Press.

Szczygiel J., 2015b - Quaternary faulting in the Tatra Mts., evidence from cave morphology and fault-slip analysis. Geologica Carpathica, 66 (3): 245-254. http://dx.doi.org/10.1515/geoca-2015-0023

Szczygieł J. \& Gaidzik K., 2012 - Tectonic setting of the Poszukiwaczy Skarbów Cave and the Groby Cave (Kraków Gorge, Western Tatra Mts., Poland). Contemporary Trends in Geoscience, 1: 93-98. http://dx.doi.org/10.2478/ctg-2012-0014

Szczygieł J., Borowska U. \& Jaglarz P., 2014 - Geological structure of the Ciemniak Massif on the basis of data from the Mała Cave in Mułowa (Western Tatra Mts.). Przegląd Geologiczny, 62 (7): 349-355. (In Polish, English summary)

Szczygieł J., Gaidzik K. \& Kicińska D., 2015 - Tectonic control of cave development: a case study of the Bystra Valley in The Tatra Mts., Poland. Annales Societatis Geologorum Poloniae, 85 (2): 387-404.

http://dx.doi.org/10.14241/asgp.2015.015

Šušteršič F., 2002 - Collapse dolines and deflector faults as indicators of karst flow corridors. International Journal of Speleology, 31 (1/4): 115-127. http://dx.doi.org/10.5038/1827-806X.31.1.6

Šušteršič F., 2006 - Relationships between deflector fault, collapse dolines and collector channel formation: some examples from Slovenia. International Journal of Speleology, 35 (1): 1-12. http://dx.doi.org/10.5038/1827-806X.35.1.1

Tîrlă L. \& Vijulie I., 2013 - Structural-tectonic controls and geomorphology of the karst corridors in alpine limestone ridges: Southern Carpathians, Romania. Geomorphology, 197: 123-136.

http://dx.doi.org/10.1016/j.geomorph.2013.05.003

Tognini P. \& Bini A., 2001 - Efects of structural setting endokarst system geometry in the Valle del Nose (Como Lake, Northern Italy). Geologica Belgica, 3: 197-211.

Wiejacz P. \& Dębski W., 2009 - Podhale, Poland, earthquake of November 30, 2004. Acta Geophysica, 57 (2): 346-366.

http://dx.doi.org/10.2478/s11600-009-0007-8

Zasadni J. \& Kłapyta P., 2014 - The Tatra Mountains during the Last Glacial Maximum. Journal of Maps, 10 (3): 440-456.

http://dx.doi.org/10.1080/17445647.2014.885854

Zupan Hajna N., 1997 - Mineral composition of clastic material in fault zones and open fissure in karst rocks, examples from SW Slovenia. In: Jeannin P.-Y. (Ed.) Proceedings of $12^{\text {th }}$ International Congress of Speleology. International Union of Speleology, La Chaux-de-Fonds, 1: 33-36. 


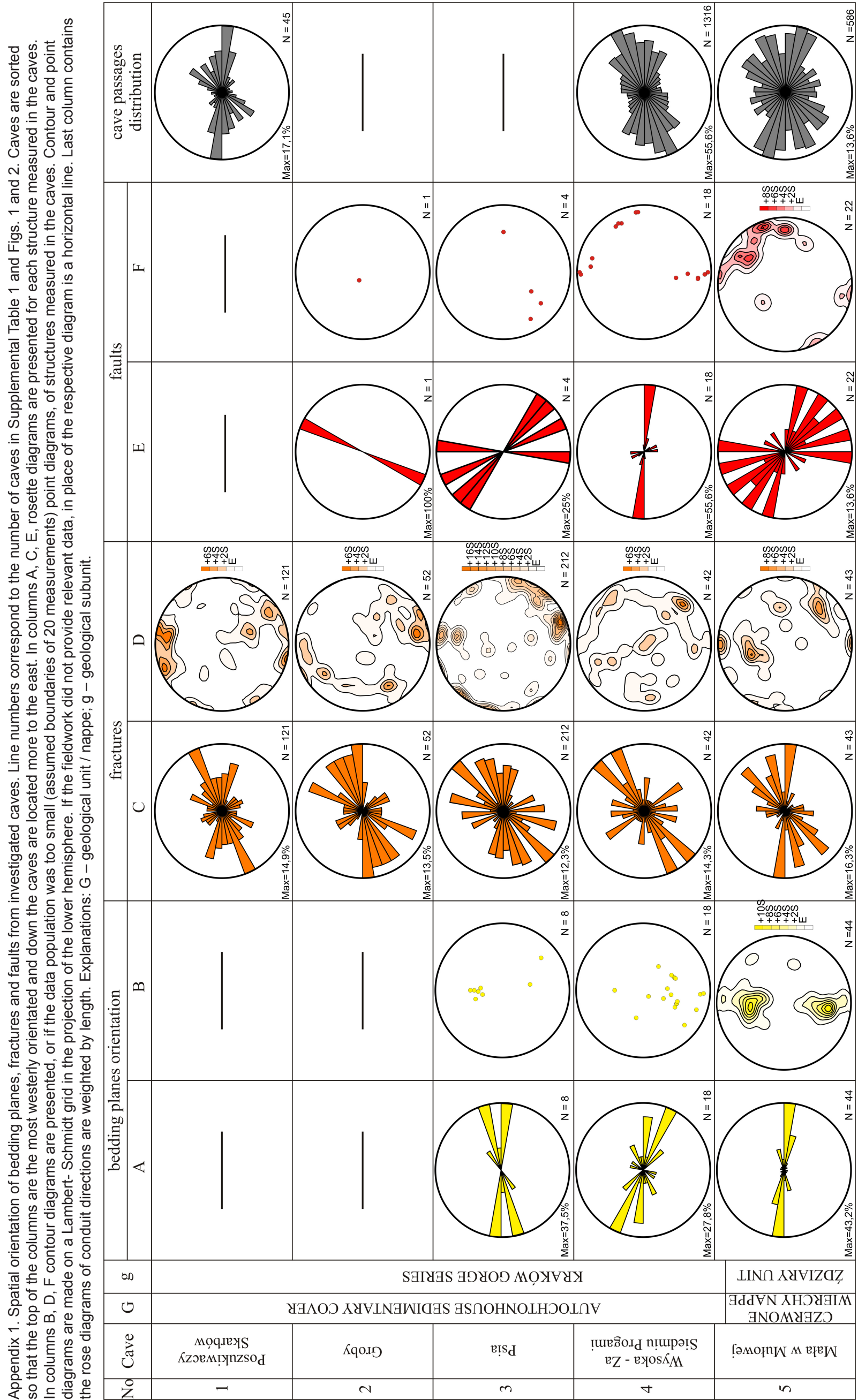



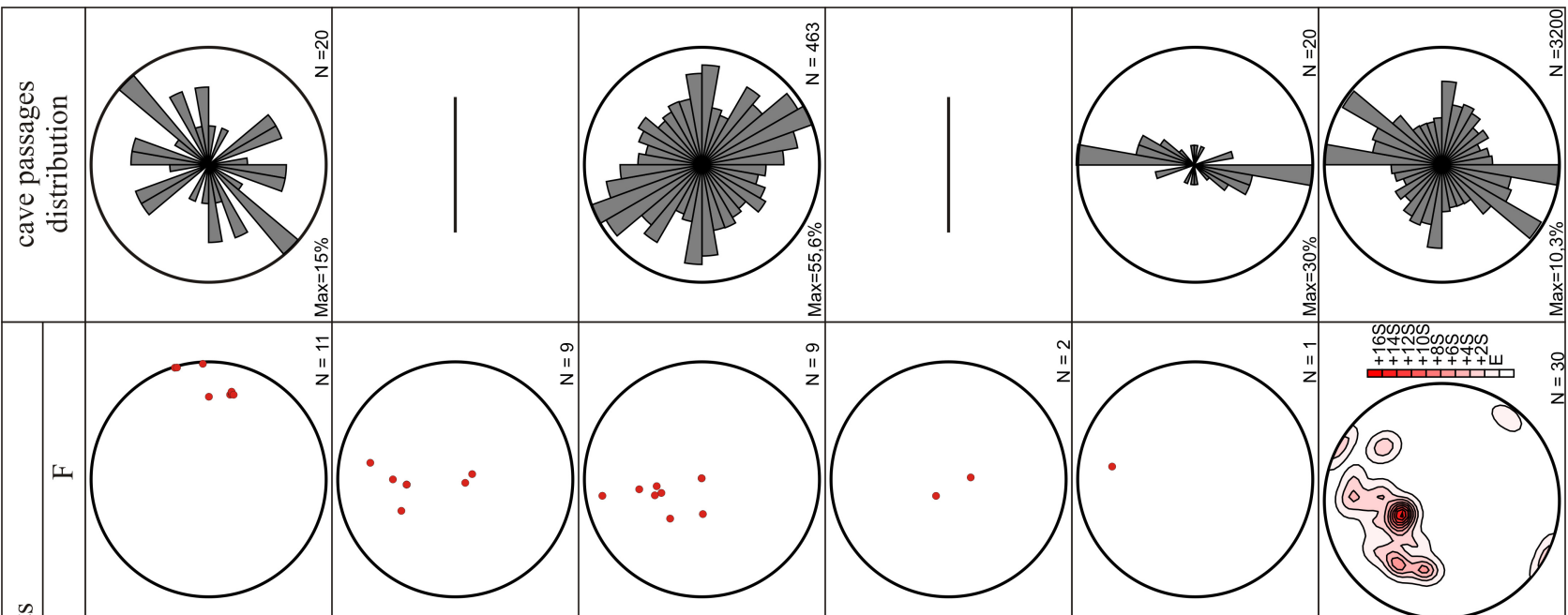

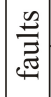
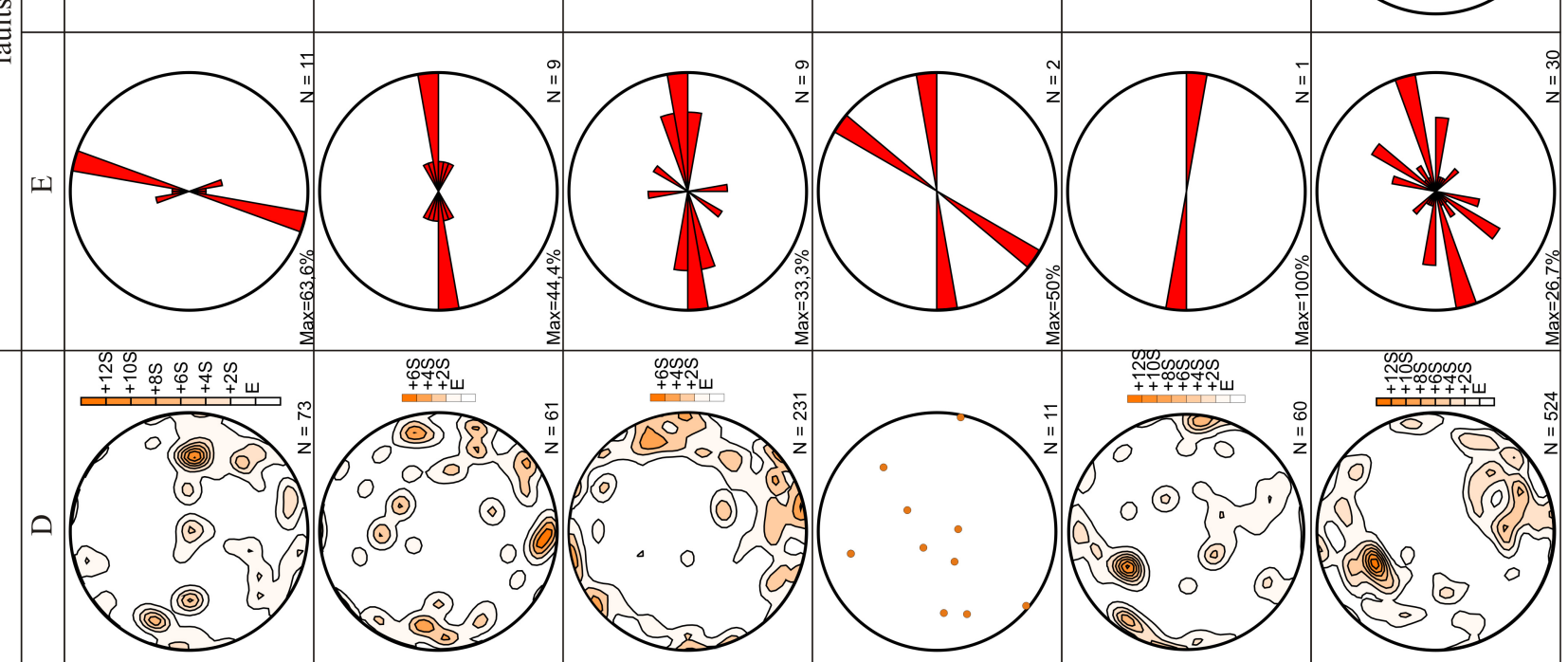

苞
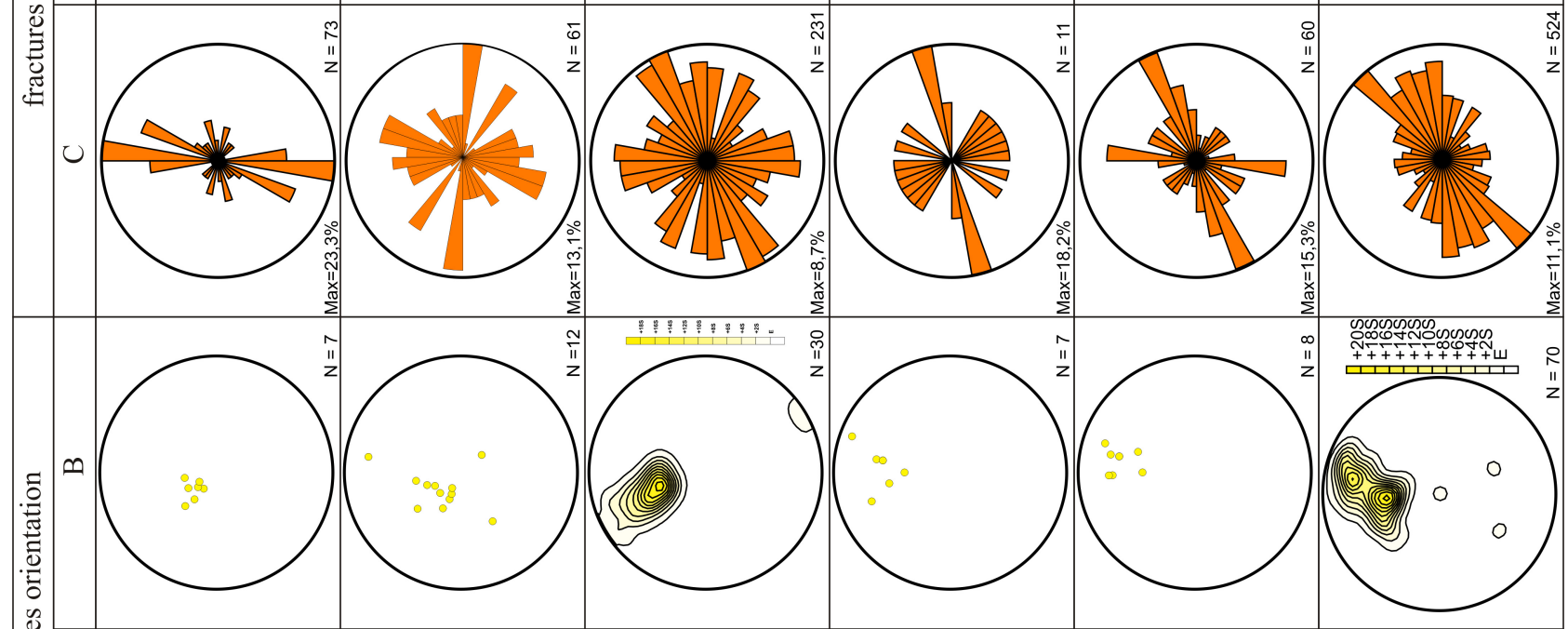

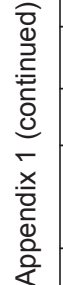

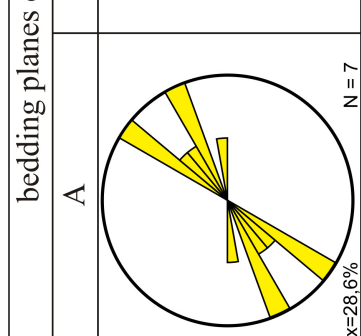

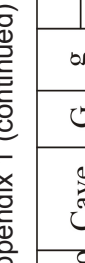

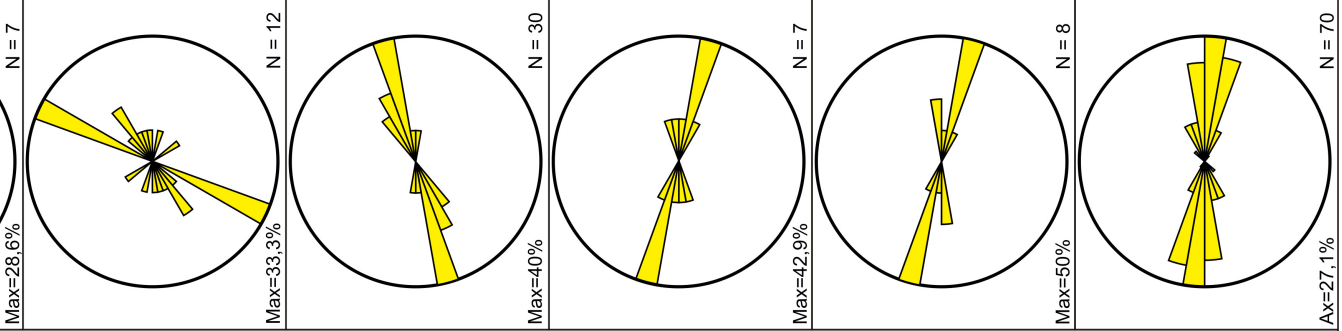

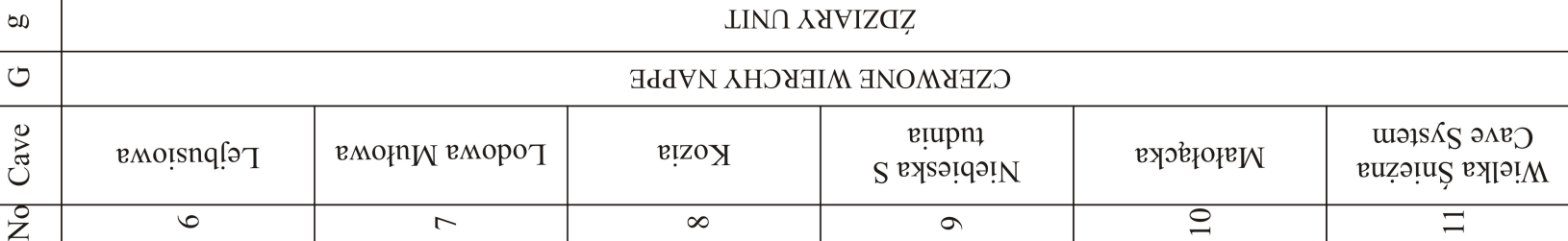



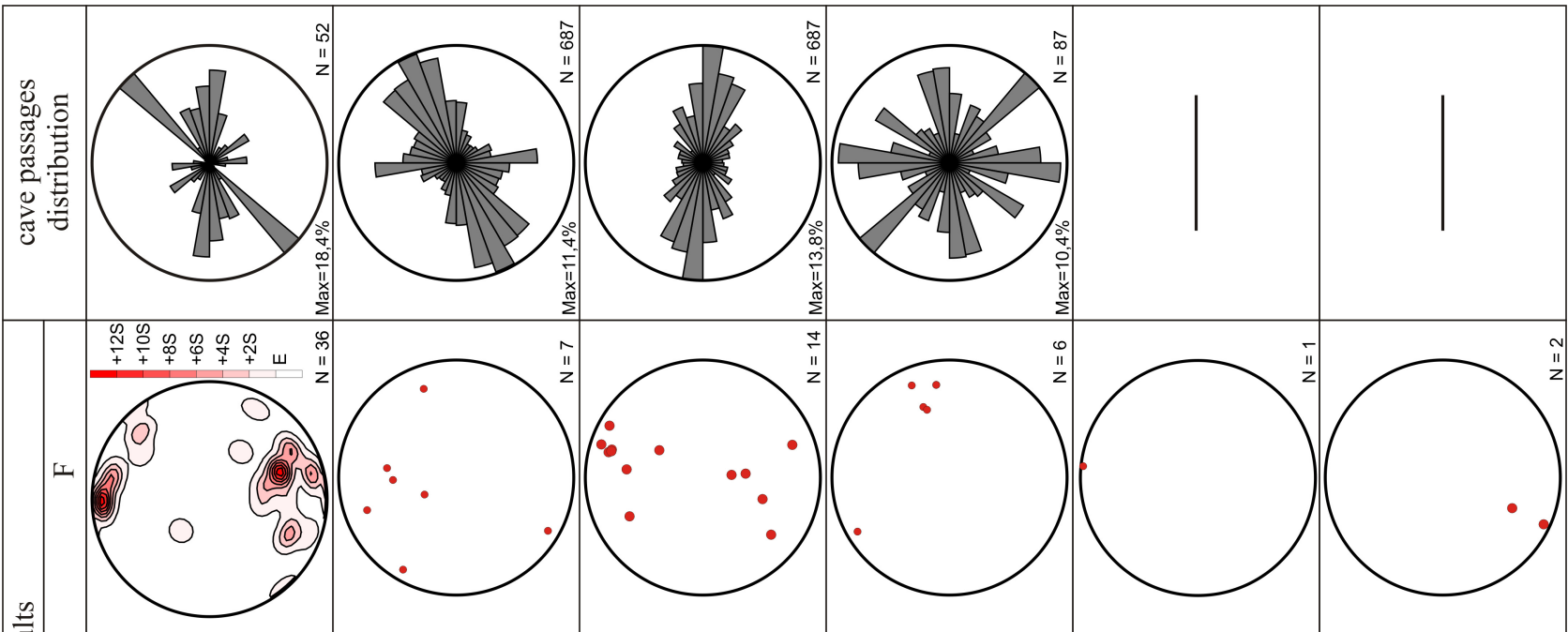

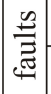
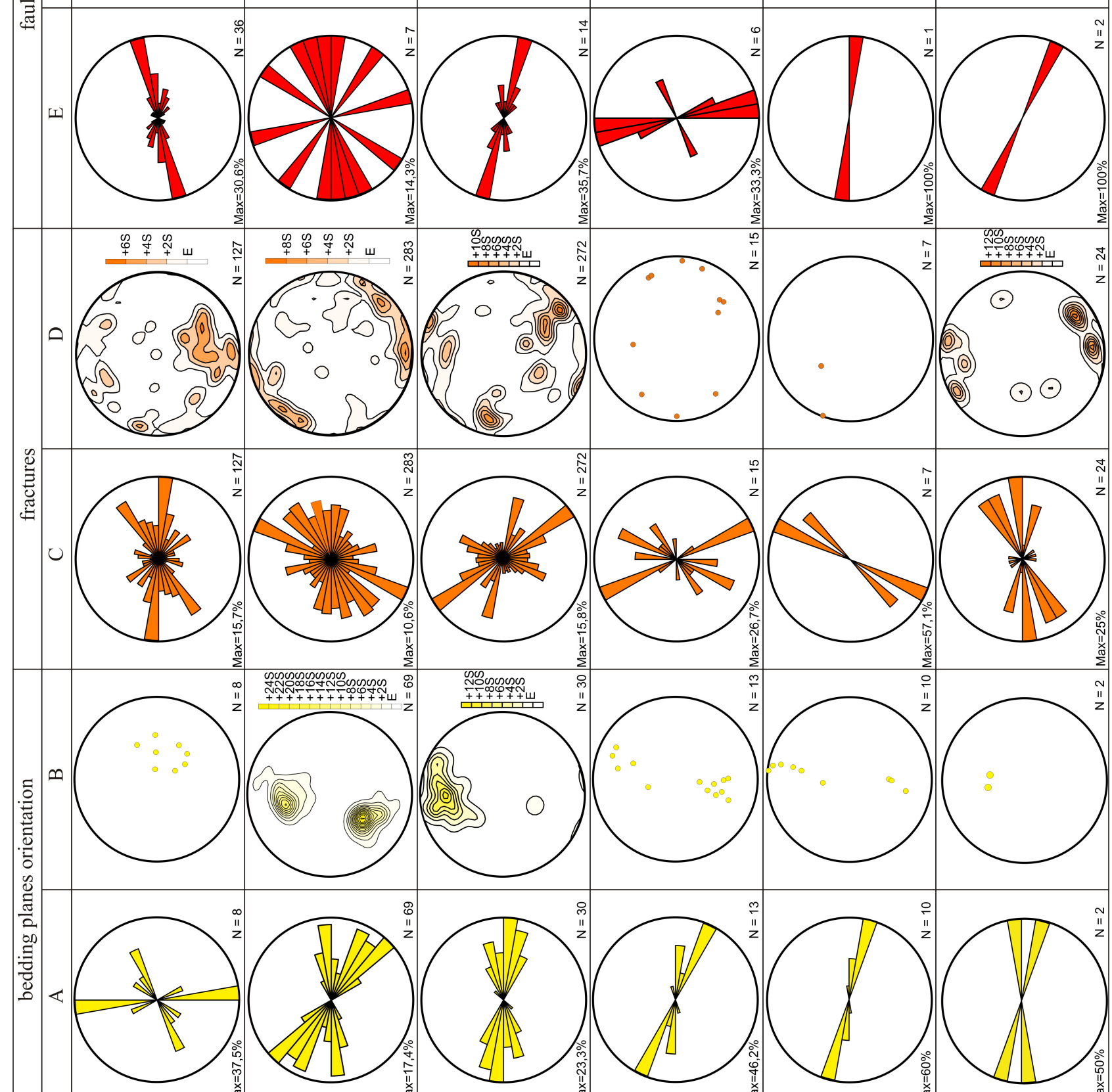

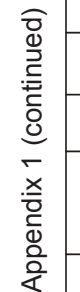

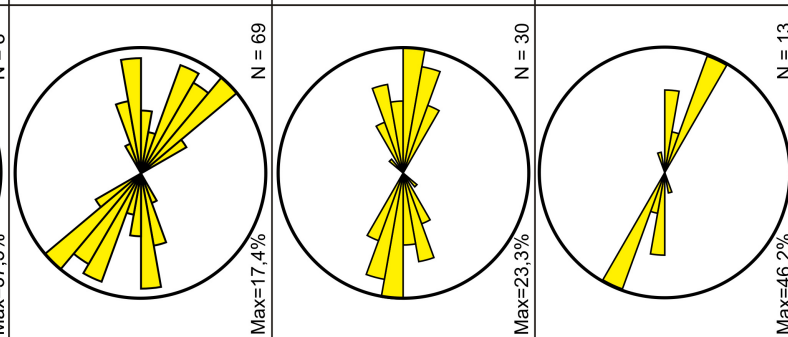

\begin{tabular}{|c|c|c|c|c|c|c|}
\hline 00 & LINO xyVIZGZ & xyVIZđZ & NVDYO & \multicolumn{3}{|c|}{ LINO XNVDYO } \\
\hline$\circlearrowright$ & \multicolumn{6}{|c|}{ ヨddVN ХНОУヨIM ヨNOMУヨZว } \\
\hline$\overbrace{\tilde{U}}^{0}$ & 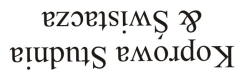 & 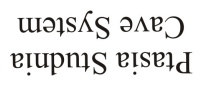 & в!̣upmS euẓə!̣uS & 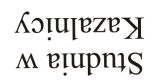 & шә.InW ez в!̣pmS & шәчюеव роd \\
\hline z & I & $\underline{m}$ & $\exists$ & $\stackrel{n}{n}$ & $\stackrel{0}{-}$ & $\underline{I}$ \\
\hline
\end{tabular}




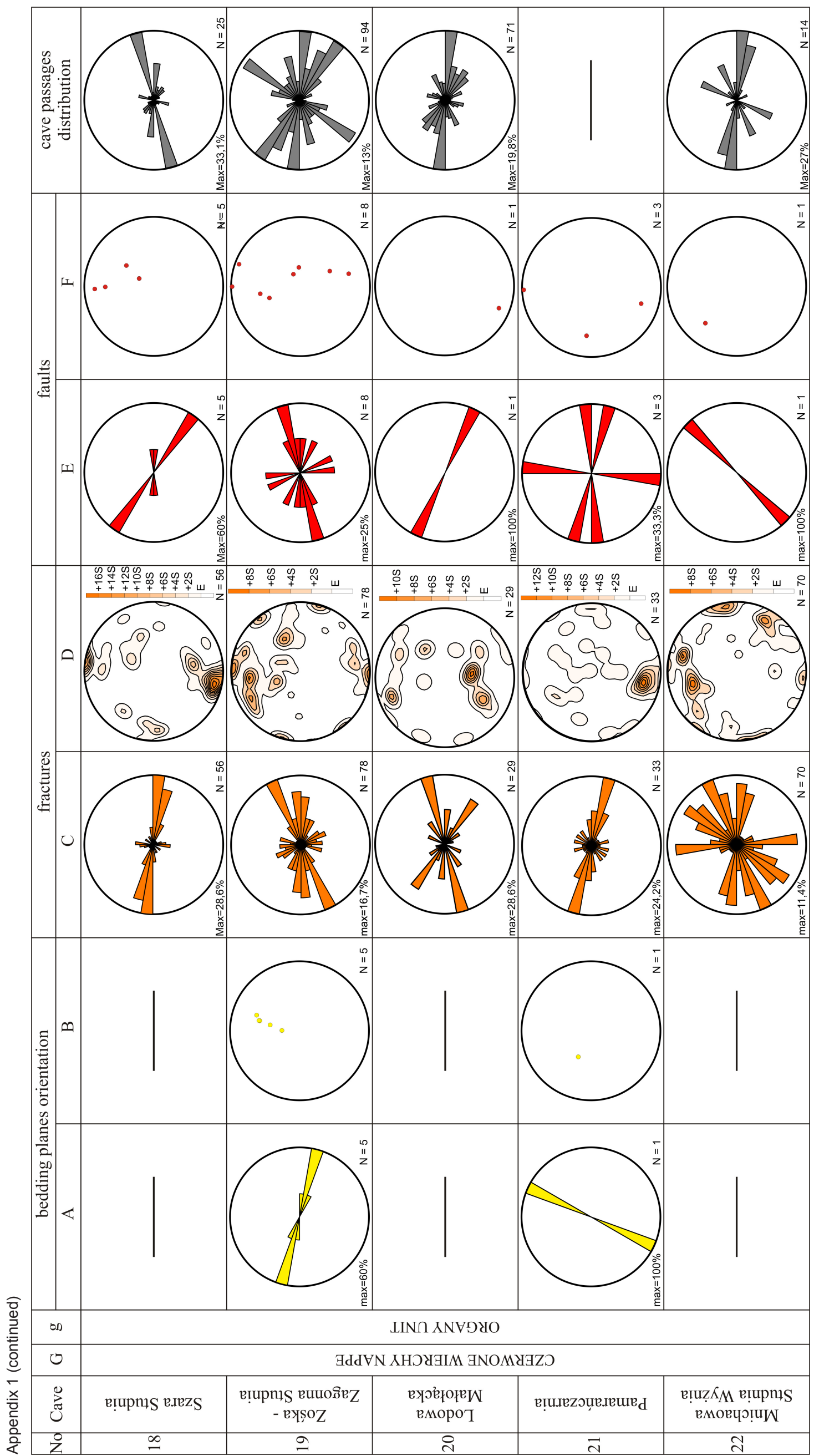

